\title{
Selected Bibliography of Statistical Literature, 1930 to 1957: III. Limit Theorems
}

\author{
Lola S. Deming
}

(January 12, 1960)

\begin{abstract}
This is the third in a series of bibliographies dealing with various specific subjects in the field of statistics. References and titles of important contributions concerning limiting distributions have been taken from technical journals published throughout the world since 1930 .
\end{abstract}

Complete coverage is not claimed in this series of bibliographies. It is believed, however, that the two prominent reviewing journals whose abstracts serve as our source material, have selected for review the writings of major statistical importance from technical journals and publishing houses throughout the world.

This particular subject classification on Limit Theorems follows two earlier ones on Correlation and Regression Theory and Time Series. ${ }^{1}$ The 675 references have been extracted from a card file of abstracts taken from Zentralblatt für Mathematik for the years 1930 to 1939, and from Mathematical Reviews for 1940 through 1957. This file of abstracts is maintained on a current basis in the NBS Statistical Engineering Laboratory. The abstracts are coded into categories of subject matter by the subject classification used in Mathematical Reviews. One abstract may be classified under several subjects, hence may appear in more than one place in this series of bibliographies.

To transcribe the material given here from the abstracts, the references were punched onto 80column cards thereby necessitating severe and unconventional abbreviations in many cases.

The following information is extracted directly from the abstracts:

Author: The author's surname is followed by initials only. In the case of complicated surnames, we have used the first capitalized word given in the reviewing journal. Multiple authorship is denoted by the symbol preceding the surname. The journal reference appears after each author's name but the title of the paper is given with the first author only.

Title: This is given exactly as in the reviewing journal. Titles of separately bound publications (books, reports, etc.) are italicized, and are followed by the publisher's name and address.

Reference to literature: The name of the journal in italies, the number of the volume in bold face, the

\footnotetext{
1 J. Research NBS 64B, 55, 69 (1960).
}

initial page number, and the date of publication in parentheses comprise the reference to the original article.

Reference to the abstract: The final symbols $M$ (for Mathematical Reviews) and Z (for Zentralblatt für Mathematik) followed by a volume number and a page number refer to the abstract of the article or book appearing in the reviewing journal.

Ackermann, W. G., Eine Erweiterung des Poissonschen Grenzwertsatzes und ihre Anwendung auf die Risikoprobleme in der Sachversicherung, Schr. Math. Inst. u. Inst. Angew. Math. Univ. Berlin 4, 211 (1939).

Z 21,343

Agnew, R. P., Global versions of the central limit theorem, Proc. Nat. Acad. Sci. U.S.A. 40, 800 (1954).

M 16, 268

Alda, V., On conditional expectations, Crechoslovak Math. J. 5, 503 (1955).

M 18, 241

Andersen, E. S., On the number of positive sums of random variables, Skand. Aktuarietidskr. 32, 27 (1949).

M 11, 256

Andersen, E. S., On the frequency of positive partial sums of a series of random variables, Mat. Tidsskr. B. 1950, 33 (1950).

M 12, 619

Andersen, E. S., On the fluctuations of the sums of random variables, Math. Scand. 1, 263 (1953).

M 15, 444

Andersen, E. S., On sums of symmetrically dependent random variables, Skand. Aktuarietidskr. 36, 123 (1953).

M 15, 634

Anis, A. A., On the distribution of the range of partial sums of independent random variables, Proc. Math. Phys. Soc. Egypt 5, 83 (1953). M 16, 267

Arfwedson, G., Research in collective risk theory. I, Skand. Aktuarietidskr 3\%, 191 (1954). M 18,275

Bachelier, L., Les lois des grands nombres du calcul des probabilités (Gauthier-Villars, Paris, 1937).

Z 16, 170

Bahn, R., Über den Grenzwert der Wahrscheinlichkeiten seltener Ereignisse, Deutsche Math. 2, 698 (1937). 
Ballarin, S., Espressione rigorosa dello scarto mediano nel problema delle prove ripetute nello schema di Bernoulli, Mem. Soc. Astr. Ital. 19, 63 (1948).

M 9, 450

Banerjee, D. P., Note on the limit of correlation and regression coefficients in mingled records, Math. Student 9, 155 (1941).

M 4, 104

Barricelli, N. A., L'intégrale relative d'une fonctionnelle et ses applications dans la théorie de la distribution de probabilité d'une courbe, Arch. Math. Naturvid. 49, 35 (1947).

M 9, 178

Bavli, G. M., Eine Verallgemeinerung des Poissonschen Grenzwertsätzes, C. R. Acad. Sci. URSS \%, 508 (1935).

$\mathrm{Z}$ 12, 216

Bawly, G. M., Über einige Verallgemeinerungen der Grenzwertsätze der Wahrscheinlichkeitsrechnung, Rec. Math. Moscou, 1, 917 (1936). I 16, 127

Bawly, G., Über den lokalen Grenzwertsatz der Wahrscheinlichkeitsrechnung, Rev. Fac. Sci. Univ. Istanbul, $\mathbf{2 ,} 79$ (1937).

Z 16, 311

Baxter, G., An analogue of the law of the iterated logarithm, Proc. Amer. Math. Soc. 6, 177 (1955).

M 16, 1128

- Bellman, R., Recurrence times for the Ehrenfest model, Pacific J. Math.1, 179 (1951). $\quad$ M 13, 566

Bellman, R., Limit theorems for non-commutative operations. I. Duke Math. J. 21, 491 (1954).

M 15, 969

Bergström, H., On the central limit theorem, Skand. Aktuarietidskr. 2\%, 139 (1944).

M $\mathbf{7}, 458$

Bergström, H., On the central limit theorem in the space $R_{k}, k>1$, Skand. Aktuarietidskr. 88,106 (1945).

M $\boldsymbol{\gamma}, 459$

Bergström, H., On the central limit theorem in the case of not equally distributed random variables, Skand. Aktuarietidskr. 32, 37 (1949).

M 11,255

Bergström, H., On distribution functions with a limiting stable distribution function, Ark. Mat. \%, 463 (1953).

M 15, 237

Bernstein, S., Sur les sommes de grandeurs aléatoires liées de classes $(\mathrm{A}, \mathrm{N})$ et $(\mathrm{B}, \mathrm{N}), C . R$. Doklady Acad. Sci. URSS 32, 303 (1941).

M 6, 88

Bernstein, S., Sur le théorème limite de la théorie des probabilités, Bull. Izvestiya Math. Mech. Inst. Univ. Tomsk 3, 174 (1946).

M 8, 471

Bernstein, S. N. (Editor), The Scientific Legacy of P. L. Čebyšev. First Part: Mathematics, (Academiya Nauk SSSR Moscow-Leningrad, 1945).

M $\%, 355$

Bernstein, S. N., Retour au problème de l'évaluation de l'approximation de la formule limite de Laplace, Bull. Acad. Sci. URSS, Ser. Math. \%, 3 (1943).

M 5, 41

Bernstein, S. N., Some remarks concerning the limit theorem of Liapunov. Doklady Akad. Nauk SSSR 24, 3 (1939).

M 1, 340

Bernstein, S., Nouvelles applications des grandeurs aléatoires presqu'indépendantes, Bull. Acad. Sci. URSS. Ser. Math. 4, 137 (1940).

M 2, 107

Bernstein, S., Sur une problème du schéma des urnes à composition variable, C. R. Doklady Acad. Sci. URSS 28, 5 (1940).
Berry, A. C., The accuracy of the Gaussian approximation to the sum of independent variates, Trans. Amer. Math. Soc. 49, 122 (1941). M 2,228

- Birnbaum, Z. W., On the properties of a collective, Amer. J. Math. 62, 787 (1940). $\quad$ M 2, 106

Bityuckov, V. I., A local limit theorem for sequences of events forming a compound chain of the second order, Izvestiya Akad. Nauk SSSR. Ser. Math. 12, 101 (1948).

M 9, 451

Blackman, J., An extension of the Kolmogorov distribution, Ann. Math. Statist. 27, 513 (1956).

M 18, 605

Blackwell, D., A renewal theorem, Duke Math. J. 15, 145 (1948).

M 9, 452

Blackwell, D.. On optimal svstems, Ann. Math. Statist. 25, 394 (1954).

M 15, 882

- Blanc-Lapierre, A., La loi forte des grands nombres pour les fonctions aléatoires stationnaires continues, C. R. Acad. Sci. Paris 220, 134 (1945).

M $\boldsymbol{7}, 129$

Blomqvist, N., On an exhaustion process, Skand. Aktuarietidskr. 35, 201 (1952).

M 14, 771

Blum, J. R., Two theorems on almost sure convergence, Proc. Amer. Math. Soc. 5, 253 (1954).

M 15, 722

Blum, J. R., On the convergence of empiric distribution functions, Ann. Math. Statist. 26, 527 (1955).

M 1\%, 48

Blum, J. R., A class of stationary processes and a central limit theorem, Duke Math. J. 24, 73 (1957)

M 18, 680

Blum, J. R., A class of stationary processes and a central limit theorem, Proc. Nat. Acad. Sci. U.S.A. 42, 412 (1956).

M 18, 342

Bobroff, A. A., Conditions of applicability of the strong law of large numbers, Duke Math. J. 12, 43 (1945).

M 6, 233

Bobrov, A. A., On the relative stability of sums of positive random quantities, Moskov. Gos. Univ. Uč. Zap. 145, Mat. 3, 92 (1949).

M 1\%, 979

Bobrov, A., Über relative Stabilität von Summen positiver zufälliger Gröben, $C . R$. Acad. Sci. URSS. 15, 239 (1937). Z 16, 410

Bobrov, A., A simplified proof of a theorem of A. N. Kolmogorov on the strong law of large numbers, Uspehi Matem. Nauk 2, 194 (1947).

М 9, 519

Bochner, S., Limit theorems for homogeneous stochastic processes, Proc. Nat. Acad. Sci. U.S.A. 40, 699 (1954).

M 16, 379

Bogolyubov, N. N., On certain limiting distributions for sums depending on arbitrary phases, Uchenye Zapiski Moskov. Gos. Univ. Fizika \%9, 43 (1945).

M $\mathbf{g}, 314$

Bogolyubov, N. N., On the influence of a random force on a harmonic oscillator, Uchenye Zapiski Moskov. Gos. Univ. Fizika $\mathbf{9}$, 51 (1945). M $\boldsymbol{g}, 314$

Bohman, H., On a class of orthogonal series, Ark. Mat. 1, 13 (1949).

M 12, 21

Borel, E., Sur les probabilités dénombrables et le pari de Pascal, C. R. Acad. Sci. Paris 224, 77 (1947).

M 8, 280

Borel, E., Sur les développements unitaires normaux, C. R. Acad. Sci. Paris 225, 51 (1947). M 9, 292 
Borel, E., Sur les développements unitaires normaux, Ann. Soc. Polon. Math. 21, 74 (1948). M 10, 132 Borel, E., Le paradoxe de Saint-Pétersbourg, $C$. $R$. Acad. Sci. Paris 229, 404 (1949). $\quad$ M 11, 118

Borel, E., Sur une propriété singulière de la limite d'une espérance mathématique, $C . R$. Acad. Sci. Paris 229, 429 (1949).

M 11, 118

Bose, P., On the limiting forms of statistical distributions, Science and Culture 9, 402 (1944).

M 5, 209

Bose, P. (see S. N. Roy) Sankhyā \%, 209 (1945).

Bottema, O., Calculation of probabilities in the game of billiards. I, Nieuw Arch. Wiskde. 2\%, 15 (1943).

M $\%, 209$

Bottema, O., Calculation of probabilities in the game of billiards. II, Nieuw Arch. Wiskunde 22, 123 (1946).

M 8, 470

Brard, R. (See A. Blanc-Lapierre), C. R. Acad. Sci. Paris 220, 134 (1945).

Broadbent, S. R., Lognormal approximation to products and quotients, Biometrika 43, 404 (1956).

M 18, 340

Brown, B. H., Simple examples of limiting processes in probability, Amer. Math. Monthly 48, 98 (1941).

M 2,228

Brunk, H. D., The strong law of large numbers, Duke Math. J. 15, 181 (1948). M 9, 450

Brunk, H. D., Note on a theorem of Kakutani, Proc. Amer. Math. Soc. 1, 409 (1950). M 12, 114

Burnens, E., Die Erfahrungsnachwirkung bei Wahrscheinlichkeiten, Mitt. Verein. Schweiz. Versich.Math. 4\%, 329 (1947).

M 9, 291

Calderon, A. P., On the moments of stochastic integrals, Sankhyā 12, 347 (1953).

M 15, 298

Cantelli, F. P., Osservazioni sulla nota "Su una teoria astratta del calcolo delle probabilità e sulla sua applicazione al teorema detto 'delle probabilità zero e uno'," Giorn. 1st. Ital. Attuari 11, 101 (1940).

M 8, 36

Cantelli, F. P., Considerazioni sulla legge uniforme dei grandi numeri. I, Atti Accad. Naz. Rend. Cl. Sci. Fis. Mat. Nat. 6, 550 (1949).

M 11, 444

Castoldi, L., Un teorema fondamentale nella teoria probabilistica degli eventi ricorrenti, Atti Accad. Ligure 11, 185 (1955).

M 18, 75

Chandrasekhar, S., On a class of probability distributions, Proc. Cambridge Philos. Soc. 45, 219 (1949).

M 10, 464

Chang, L. C., On the ratio of an empirical distribution function to the theoretical distribution function, Acta Math. Sinica 5, 347 (1955). M 17, 865

Chapelon, J., Sur un théorème fondamental du calcul des probabilités, J. École Polytechn, III 143, 161 (1937).

$\mathrm{Z} \mathrm{16,} 127$

Cheng, T. T., On the combination of statistical elements, Coll. Papers Sci. Engin. Nat. Univ. Amoy 1, 73 (1943).

M 8, 214

Cheng, T. T., On asymptotic expansions connected with the sums of independent random variables, Acta. Math. Sinica 5, 91 (1955).

M 1\%, 275
Chu, J. T., Errors in normal approximations to the $t, \tau$, and similar types of distribution, Ann. Math. Statist. 2\%, 780 (1956).

M 18, 423

Chu, J. T., The 'inefficiency' of the sample median for many familiar symmetric distributions, Biometrika 42, 520 (1955).

M 1\%, 169

Chung, K. L., On the maximum partial sums of sequences of independent random variables, Trans. Amer. Math. Soc. 64, 205 (1948). M 10, 132

Chung, K. L., Asymptotic distribution of the maximum cumulative sum of independent random variables, Bull. Amer. Math. Soc. 54, 1162 (1948).

M 10, 384

Chung, K. L., An estimate concerning the Kolmogoroff limit distribution, Trans. Amer. Math. Soc. 6\%, 36 (1949).

M 11, 606

Chung, K. L., Fluctuations of sums of independent random variables, Ann. of Math. 51, 697 (1950).

M 11, 731

Chung, K. L., The strong law of large numbers, Proc. Second Berkeley Symp. Math. Stat and Prob. (U. Calif. Press, Los Angeles, 1951). M 13, 567 Chung, K. L., Sur les lois de probabilité unimodales, C. R. Acad. Sci. Paris 236, 583 (1953). M 14, 771

Chung, K. L., On the application of the BorelCantelli lemma, Trans. Amer. Math. Soc. \%9, 179 (1952).

M 13, 567

Chung, K. L., Remarks on fluctuations of sums of independent random variables, Mem. Amer. Math. Soc. No. 6 (1951). n M 12, 722

Chung, K. L., On the zeros of $\Sigma \pm 1$, Ann. of Math. 50, 385 (1949). 11 M 10,613

Chung, K. L., On the distributions of values of sums of random variables, Mem. Amer. Math. Soc. No. 6 (1951). M 12, 722

Chung, K. L., Corrections to the paper "Remarks on fluctuations of sums of independent random variables," Proc. Amer. Math. Soc. 4, 560 (1953).

M 15, 44

Chung, K. L., An extension of renewal theory, Proc. Amer. Math. Soc. 3, 303 (1952). M 14, 61

- Chung, K. L. (See P. L. Hsu) C.R. Acad Sci. Paris 293, 467 (1946).

Chung, K. L., On a limit theorem in renewal theory, Ann. of Math. 55, 1 (1952). M 13, 475

Chung, K. L., Note on some strong laws of large numbers, Amer. J. Math. 69, 189 (1947).

M 8, 471

Chung, K. L., On the maximum partial sum of independent random variables, Proc. Nat. Acad. Sci. U.S.A. 33, 132 (1947). M 9, 96

Chung, K. L., On a lemma by Kolmogoroff, Ann. Math. Statist. 19, 88 (1948). M 9, 360

Ciucu, G., La loi des grands nombres pour les variables aléatoires liées, Com. Acad. R. P. Romîne 5, 1253 (1955).

M 1\%, 1217

Consael, R., Sur le schéma de Pólya-Eggenberger à deux variables aléatoires, Assoc. Actuair. Belges. Bull. No. 5511 (1949).

M 11, 605

Consoli, T., Généralisation d'un théorème sur la probabilité de la somme d'un nombre infini de variables aléatoires, Rev. Fac. Sci. Univ. Istanbul (A) 5, 1 (1940). 
Copeland, A. H., The probability limit theorem, Duke Math. J. 2, 171 (1936).

Z 13, 273

Cote, L. J., On fluctuations of sums of random variables, Proc. Amer. Math. Soc. 6, 135 (1955).

M 1\%, 48

Cox, D. R., A direct proof of a fundamental theorem of renewal theory, Skand. Aktuarietidskr. 36, 139 (1953).

M 15, 722

Cramér, H., Les sommes et les fonctions de variables aléatoires, Actualités Scient. et Industr. No. 736 (Hermann \& Cie, Paris, 1938).

Z 22, 241

Cramér, H., On some questions connected with mathematical risk, Univ. California Publ. Statist. 2, 99 (1954).

M 16, 494

Cramér, H., Mathematical Methods of Statistics (Princeton University Press, Princeton, N.J., 1946).

M 8, 39

Curtiss, J. H., Convergent sequences of probability distributions, Amer. Math. Monthly 50, 94 (1943).

M 4, 248

Daniels, H. E., The statistical theory of the strength of bundles of threads. I. Proc. Roy. Soc. London Ser. A 183, 405 (1945).

M \%, 19

van Dantzig, D., Another form of the weak law of large numbers, Niew Arch. Wiskunde 1, 129 (1953).

M 15, 140

Darling, D. A., Sums of symmetrical random variables, Proc. Amer. Math. Soc. 2, 511 (1951).

M 13, 258

Darling, D. A., The maximum of sums of stable random variables, Trans. Amer. Math. Soc. 83, 164 (1956).

M 18, 240

- Darling, D. A., On occupation times for Markoff processes, Trans. Amer. Math. Soc. 84, 444 (1957).

M 18, 832

Darling, D. A., The influence of the maximum term in the addition of independent random variables, Trans. Amer. Math. Soc. $\mathbf{3 3 ,} 95$ (1952). M 14, 60

Darling, D. A., A limit theorem for the maximum of normalized sums of independent random variables, Duke Math. J. 23, 143 (1956). M 1\%, 635

David, H. T., A note on random walk, Ann. Math. Statist. 20, 603 (1949).

M 11, 375

Davis, R. C., On the theory of prediction of nonstationary stochastic processes, J. Appl. Phys. 23, 1047 (1952).

M 14, 295

Derksen, J. B. D., On some infinite series introduced by Tschuprow, Ann. Math. Statist. 10, 380 (1939).

M 1, 152

Derman, C., The strong law of large numbers when the first moment does not exist, Proc. Nat. Acad. Sci. U.S.A. 41, 586 (1955).

M 1\%, 48

Derman, C., A note on nonrecurrent random walks, Proc. Amer. Math. Soc. \%, 762 (1956). M 18, 681

Derman, C., Some asymptotic distribution theory for Markov chains with a denumerable number of states, Biometrika 43, 285 (1956). $\quad$ M 18, 519

Diananda, P. H., The central limit theorem for $m$ dependent variables, Proc. Cambridge Philos. Soc. 51, 92 (1955).

M 16, 724

Diananda, P. H., Some probability limit theorems with statistical applications, Proc. Cambridge
Philos. Soc. 49, 239 (1953).

M 14, 771

Diananda, P. H., The central limit theorem for $m$ dependent variables asymptotically stationary to second order, Proc. Cambridge Philos. Soc. 50, 287 (1954).

M 15, 635

Dieulefait, C. E., Some new derivations of limiting probability functions, Univ. Nac. Tucumán. Revista A. 2, 25 (1941).

M 4, 16

Dieulefait, C. E., On Slutsky's sinusoidal limit law, derived from a new sequence of random variables, An. Soc. Ci. Argentina 134, 257 (1942). M 5, 207

Dilworth, R. P., Note on the strong law of large numbers, Amer. Math. Monthly 56, 249 (1949).

M 10, 720

Dobrušin, R. L., On Poisson's law for distribution of particles in space, Ukrain. Mat. Ž. 8, 127 (1956).

M 18, 341

Dobrušin, R. L., Limit theorems for a Markov chain of two states, Izvestiya Akad. Nauk SSSR. Ser. Mat. 1\%, 291 (1953).

M 15, 329

Dobrušin, R. L., Central limit theorem for nonstationary Markov chains, Dokl. Akad. Nauk SSSR. 102, 5 (1955).

M 1\%, 48

Dobrušin, R. L., Two limit theorems for the simplest random walk on a line, Uspehi Mat. Nauk 10, 139 (1955).

M 1\%, 166

Dobrušin, R. L., Lemma on the limit of compound random functions, Uspehi. Mat. Nauk 10, 157 (1955).

M 1\%, 48

Doeblin, W., Sur un problème de calcul des probabilités, C. R. Acad. Sci. Paris 209, 742 (1939).

M 1, 149

Doeblin, W., Sur l'ensemble de puissances d'une loi de probabilité, Studia Math.9, 71 (1940). M 3, 168

- Dolph, C. L., On the relation between Green's functions and covariances of certain stochastic processes and its application to unbiased linear prediction, Trans. Amer. Math. Soc. \%2, 519 (1952).

M 14, 295

Domb, C., The resultant of a large number of events of random phase, Proc. Cambridge Philos. Soc. 4\%, 245 (1946).

M 8, 281

Doob, J. L., Application of the theory of martingales, Colloq. Internat. Centre Nat. Rech. Sci. Paris 13, 23 (1949).

M 11, 444

Doob, J. L., The law of large numbers for continuous stochastic processes, Duke Math. J. 6, 290 (1940).

M 1, 344

Doss, S., Sur la convergence stochastique dans les espaces uniformes, Ann. Sci. Ecole Norm. Sup. $\mathbf{1 1}$ 87 (1954).

M 16, 724

Doss, S., Sur le théorème limite central pour des variables aléatoires dans un espace de Banach, Publ. Inst. Statist. Univ. Paris 3, 143 (1954).

M 16, 724

Downton, F., On limiting distributions arising in bulk service queues, J. Roy. Statist. Soc. B 18, 265 (1956).

M 18, 547

Dubourdieu, J., Sur une généralisation d'un théorème de M. B. de Finetti et son application à la théorie collective du risque, C. R. Acad. Sci. Paris $\mathbf{2 2 4}$, 514 (1947).
M 8, 390 
Dubourdieu, M. J., Sur un théorème de M. S. Bernstein relatif à la transformation de LaplaceStieltjes, Compositio Math., 96 (1939). M 1, 73

Dugué, D., Incompatibilité de la convergence presque certaine et de l'écart, $C . R$. Acad. Sci. Paris 242, 728 (1956).

M 1\%, 864

Dugué, D., Sur le second théorème limite du calcul des probabilités, C. R. Acad Sci. Paris 242, 444 (1956).

M 1\%, 635

Dugué, D., Deux notions utiles en statistique mathématique: les ensembles aléatoires bornés "en loi" et la continuité fortement uniforme en probabilité, Colloq. sur l'Analyse Statist., Bruxelles 1954 pp. 133-141. (Masson \& Cie, Paris, 1955)

M 1\%, 635

Dugué, D., Sur les théorèmes limites du calcul des probabilités, Rev. Inst. Internal. Statist. $\mathbf{2 3 ,} 29$ (1955).

M 18, 156

Dugué, D., Sur la convergence presque complète des moyennes de variables aléatoires (théorèmes de Hsu, Robbins et Erdös), Publ. Inst. Statist. Univ. Paris 3, 149 (1954).

M 16, 600

Dugué, D., L' existence d'une norme est incompatible avec la convergence en probabilité, $C$. $R$. Acad. Sci. Paris 240, 1307 (1955).

M 16, 1035

Dugué, D., Sur une extension de la loi des grands nombres, C. R. Acad. Sci., Paris 204, 317 (1937)

Z 15, 406

Dugué, D., Sur la convergence presque certaine au sens de Cesàro de variables aléatoires et sur certaines inégalités concernant les fonctions caractéristiques, C. R. Acad. Sci. Paris $\mathbf{2 3 4 ,} 1837$ (1952).

M 13, 853

Dvoretzky, A., On the strong stability of a sequence of events, Ann. Math. Statist. 20, 296 (1949).

M 11, 189

Dvoretzky, A., Sums of random integers reduced molulo m, Duke Math. J. 18, 501 (1951).

M 12, 839

Dwass, M., On the asymptotic normality of some statistics used in non-parametric tests, Ann. Math. Statist. 26, 334 (1955).

M 16, 1038

Dynkin, E. B., Infinitesimal operators of Markov random processes, Dokl. Akad. Nauk. SSSR. 105, 206 (1955).

M 1\%, 866

Dynkin, E. B., Some limit theorems for sums of independent random quantities with infinite mathematical expectations, Izv. Akad. Nauk. SSSR. Ser. Mat. 19, 247 (1955).

M 1\%, 865

van Elteren, Ph., The asymptotic distribution for large $m$ of 'Terpstra's statistic for the problem of $m$ rankings, Math. Centrum Amsterdam Statist. Rep. $S$ 212, 14 pp. (1956).

M 18, 519

Epstein, B., The mathematical description of certain breakage mechanisms leading to the logarithmiconormal distribution, J. Franklin Inst. 244, 471 (1947).

M 9, 360

- Erdös, P., On the law of the iterated logarithm. I, II, Indag. Math. 1\%, 65, and 77 (1955). M 16, 1016

Erdös, P., On the law of the iterated logarithm, Ann. of Math. 43, 419 (1942).

M 4, 16

Erdos, P., On a theorem of Hsu and Robbins, Ann. Math. Statist. 20, 286 (1949).
Erdös, P., Remark on my paper "On a theorem of Hsu and Robbins," Ann. Math. Statist. 21, 138 (1950).

M 11, 375

Erdös, P., On the strong law of large numbers, Trans. Amer. Math. Soc. 6\%, 51 (1949).

M 11, 375

Erdös, P., Changes of sign of sums of random variables, Pacific J. Math. 3, 673 (1953). M 15, 444

Erdös, P., The Gaussian law of errors in the theory of additive number theoretic functions, Amer. $\bar{J}$. Math. 62, 738 (1940)

M $\boldsymbol{2}, 42$

Erdös, P., On certain limit theorems of the theory of probability, Bull. Amer. Math. Soc. 52, 292 (1946).

M 7,459

Erdös, P., (See D. A. Darling) Duke Math. J. 23, $143(1956)$.

Erdös, P., (See K. L. Chung) Trans. Amer. Math. Soc. \%?, 179 (1952).

Esseen, C. G., On the Liapounoff limit of error in the theory of probability, Ark. Mat. Astr. Fys. 28A, No. 9 (1942).

M 6, 232

Esseen, C. G., Determination of the maximum deviation from the Gaussian law, Ark. Mat. Astr. Fys29A, No. 20 (1943).

M 6, 233

Esseen, C. G., Fourier analysis of distribution func. tions. A mathematical study of the LaplaceGaussian law, Acta. Math. \%8, 1 (1945).

M $\%, 312$

Fan, K., Entfernung zweier zufälligen Grössen und die Konvergenz nach Wahrscheinlichkeit, Math. Z. 49, 681 (1944).

M 6, 232

Fan, K., Sur l'extension de la formule générale d'interpolation de M. Borel aux fonctions aléatoires, C. R. Acad. Sci. Paris 218, 260 (1944).

M \%, 128

Fan, K., Sur l'approximation et l'intégration des fonctions aléatoires, Bull. Soc. Math. France $\mathbf{9 \% ,} 97$ (1944).

M \%, 129

Fan, K., Généralisations du théorème de $M$. Khintchine sur la validité de la loi des grands nombres pour les suites stationnaires de variables aléatoires, C. R. Acad. Sci. Paris 220, 102 (1945).

M $\boldsymbol{\gamma}, 128$

Fan, K., Two mean theorems in Hilbert space, Proc. Nat. Acad. Sci. U.S.A. 31, 417 (1945). M \%, 309

Feldheim, E., Une loi-limite du calcul des probabilités, Acta. Litt. Sci. Szeged 8, 55 (1936).

$\mathrm{Z} \mathrm{14,72}$

Feldheim, E., Nuova dimostrazione e generalizzazione di un teorema di calcolo delle probabilità, Giorn. 1st. Ital. Attuari 10, 229 (1939). M 1, 246

Feldheim, E., Nouvelle démonstration et généralisation d'un théorème du calcul des probabilités dû à Simmons, J. Math. Pures Appl. 20, 1 (1941).

M 3, 1

Feller, W., On probability problems in the theory of counters, Studies and essays presented to $\mathrm{R}$. Courant, pp. 105-115 (Interscience Publishers, N.Y., 1948).

M 9, 294

Feller, W., The asymptotic distribution of the range of sums of independent random variables, $A n n$. Math. Statist. 22, 427 (1951).

M 13, 140 
Feller, W., Über den zentralen Grenzwertsatz der Wahrscheinlichkeitsrechnung, Math. Z. 40, 521 (1935).

$\mathrm{Z}$ 12, 361

Feller, W., Über den zentralen Grenzwertsatz der Wahrscheinlichkeitsrechnung, II, Math. Z. 42, 301 (1937).

Z 15, 360

Feller, W., Über das Gesetz der groben Zahlen, Acta Litt. Sci. Szeged 8, 191 (1937).

Z 16, 411

Feller, W., Generalization of a probability limit theorem of Cramér, Trans. Amer. Math. Soc. 54, 361 (1943).

M 5, 125

Feller, W., Errata (Corrections to papers in Ann. Math. Statist. 16, 319 (1945) and 19, 177 (1948), Ann. Math. Statist. 21, 301 (1950).

M 11, 674

Feller, W., The general form of the so-called law of the iterated logarithm, Trans. Amer. Math. Soc. 54, 373 (1943).

M 5, 125

Feller, W., The fundamental limit theorems in probability, Bull. Amer. Math. Soc. 51, 800 (1945).

M $\boldsymbol{y}, 128$

Feller, W., Note on the law of large numbers and "fair" games, Ann. Math. Statist. 16, 301 (1945).

M $\boldsymbol{y}, 128$

Feller, W., On the normal approximation to the binomial distribution, Ann. Math. Statist. 16, 319 (1945).

M $\boldsymbol{g}, 459$

Feller, W., A limit theorem for random variables with infinite moments, Amer. J. Math. 68, 257 (1946).

M 8, 37

Feller, W., The law of the iterated logarithm for identically distributed random variables, $A n n$. of Math. 4\%, 631 (1946).

M 8, 214

Feller, W., On the Kolmogorov-Smirnov limit theorems for empirical distributions, Ann. Math. Statist. 19, 177 (1948).

M 9, 599

Feller, W., The fundamental limit theorems in probability, Revista Mat. Hisp.-Amer. 8, 95 (1948).

M 10, 310

Feller, W., Fluctuation theory of recurrent events, Trans. Amer. Math. Soc. 67, 98 (1949). M 11, 255

- Ferrand, J., Sur des suites arithmétiques équiréparties, C. R. Acad. Sci. Paris 224, 516 (1947).

M 8, 391

Finkel'steřn, B. V., Limiting distribution of the terms of a variational series of quantities related by a stationary Markov chain, Ukrain. Mat. Z. \%, 313 (1955).

M 1\%, 1217

Finkel'štern, B. V., On the limiting distributions of the extreme terms of a variational series of a twodimensional random quantity, Doklady Akad. Nauk SSSR 91, 209 (1953).

M 15, 444

Fisz, M., Accuracy of an asymptotical formula, Zastos. Mat. 2, 62 (1954).

M 16, 1034

-Fisz, M., Analytical characterization of a composed, non-homogeneous Poisson process, Studia Math. 15, 328 (1956).

M 18, 605

Fisz, M., The limiting distributions of sums of arbitrary independent and equally distributed $r$-point $(r \geq 2)$ random variables, Bull. Acad. Polon. Sci. Cl. IIII, 1, 235 (1953).

M 15, 635
Fisz, M., The limiting distributions of the multinomial distribution, Studia Math. 14, 272 (1955).

M 16, 839

Fisz, M., A limit theorem for a modified Bernouilli scheme, Studia Math. 15, 80 (1955). M 1\%, 634

Fisz, M., The limiting distribution of the difference of two Poisson random variables, Zastosowania Mat. 1, 41 (1953).

M 15, 138

Fisz, M., The limiting distributions of sums of arbitrary independent and equally distributed $r$-point random variables, Studia Math. 14, 111 (1954).

M 15, 882

Forsythe, G. E., Cesàro summability of independent random variables, Duke Math. J. 10, 397 (1943).

M 5, 41

Fortet, R., Normalverteilte Zufallselemente in Banachschen Räumen. Anwendungen auf zufällige Funktionen, Ber. Wahrsch. und Statist., pp. 29-35. (Verlag Wissenschaften, Berlin, 1956). M 18, 519

Fortet, R., Sur une suite également répartie, Studia Math. 9, 54 (1940).

M 3, 169

Fortet, R., (See J. Ferrand) C.R. Acad. Sci. Paris 224, 516 (1947).

Fortet, R., Sur une suite également répartie, Rev. Sci. 78, 298 (1940).

M \%, 128

Fortet, R., Random functions from a Poisson process, Proc. Symp. Math. Prob. pp. 373-385 (Univ. Cal. Press, Berkeley 1951). M 13, 958

Fortet, R., On some functionals of Laplacian processes, J. Research NBS 48, 32 (1952). M 13, 958

- Fortet, R., Résultats complémentaires sur les éléments aléatoires prenant leurs valeurs dans un espace de Banach, Bull. Sci. Math. 98, 14 (1954).

\section{16, 149}

- Fortet, R., Loi des grands nombres et théorie ergodique, C. R. Acad. Sci. Paris 234, 699 (1952).

M 14, 387

Fortet, R., Convergence de la répartition empirique vers la répartition théorique, $C . R$. Acad. Sci. Paris 236, 1739 (1953).

M 14, 993

- Fortet, R., Lois des grands nombres pour des éléments aléatoires prenant leurs valeurs dans un espace de Banach, C. R. Acad. Sci. Paris $\mathbf{2 3 \%}$, 18 (1953).

M 15, 44

- Fortet, R., Convergence de la répartition empirique vers la répartition théorique, Ann. Sci. École Norm. Sup. \%0, 267 (1953).

M 15, 808

Fortet, R., Sur les fonctionnelles de certaines fonctions aléatoires, C. R. Acad. Sci. Paris 238, 1557 (1954).

M 15, 805

Franckx, E., La loi faible des grands nombres des variables stochastiques uniformément bornées, Acad. Roy. Belg. Bull. Cl. Sci. 42, 47 (1956).

M 1\%, 864

Franckx, E., Généralisation d'un théorème de Borel, Trabajos Estadistica 4, 369 (1953).

M 15, 722

Fraser, D. A. S., A vector form of the Wald-Wolfowitz-Hoeffding theorem, Ann. Math. Statist. 2\%, 540 (1956).

M 1\%, 1219

Fréchet, M., Sulla mescolanza delle palline e sulle leggi-limite delle probabilità, Giorn. Ist. Ital. Attuari 8, 14 (1937).
Z 16, 128 
Fréchet, M., Statistical Self-Renewing AggregatesA Course of Lectures Delivered at the Faculty of Science, Fouad I University, (Fouad I University Press, Cairo 1949).

M 11, 606

Fréchet, M., Généralisations de la loi de probabilité de Laplace, Ann. Inst. H. Poincaré 12, 1 (1951).

M 12, 839

Freı̌man, G. A., An elementary method of proof of limit theorems of the theory of probability. Vestnik Leningrad Univ. 11, 57 (1956).

M 1\%, 1096

Freudenthal, H., Gambling with a poor chance of gain, Nederl. Akad. Wetensch. Proc. Ser. A $\mathbf{5 5}$ (1952).

M 14, 387

Freudenthal, H., A limit free formulation of the weak law of large numbers, Nederl. Akad. Wetensch. Proc. Ser. A $\mathbf{5 5}$ (1952).

M 14, 387

Friedman, B., A simple urn model, Comm. Pure Appl. Math 2, 59 (1949).

Fuchs, W. H. J. (See K. L. Chung) Mem. Amer. Math. Soc. No. 6, (1951).

Fukamiya, M., The Lipschitz condition of random function, Tôhoku Math. J. 46, 145 (1939).

M 1, 149

Gál, I. S. (See P. Erdös) Indag. Math. 1\%, 65-77 (1955).

Gál, I. S., Sur l'ordre de grandeur des fonctions sommables, C. R. Acad. Sci. Paris 228, 636 (1949).

M 10, 550

Gani, J., The condition of regularity in simple Markov chains, Austral. J. Phys. 9, 387 (1956).

M 18, 520

Garti, Y., Les lois de probabilité pour les fonctions statistiques (cas de collectifs à plusieurs dimensions), Rev. Math. Union Interbalkan 3, 21 (1940).

M 2,106

Gartšteinn, B. N., On the limiting distribution of the extreme and mixed ranges of a variational series, Dopovidi Akad. Nauk Ukrain. RSR 1951, 25 (1951).

M 15, 722

Gasapina, U., Un teorema limite del calcolo delle probabilità, Atti Cong. Un. Mat. Italiana II, pp. 599-609. (Casa Editrice Perrella, Roma, 1953).

M 15, 43

Geiringer, H., Sur des variables aléatoires arbitrairement liées. Cas de convergence vers la loi Gauss, C. R. Acad. Sci. Paris 204, 1914 (1937).

Z 16, 364

Geiringer, H., Sur les variables aléatoires arbitrairement liées (Convergence vers la loi de Poisson), C.R. Acad. Sci. Paris 204, 1856 (1937). Z 16, 364

Geiringer, H., A generalization of the law of large numbers, Ann. Math. Statist. 11, 393 (1940).

M 2, 228

Ghosh. M. N., On the order of approximation involved in Laplace's central limit theorem in probability. Sankhyā $\boldsymbol{\gamma}, 323$ (1946). M 8, 36

Ghosh, M. N., Convergence of random distribution functions, Bull. Calcutta Math. Soc. 42, 217 (1950).

M 13, 140

Gihman, I. I., On the empirical distribution function in the case of grouping of the data, Doklady Akad. Nauk. SSSR. 82, 837 (1952).
Gihman, I. I., On a theorem of A. N. Kolmogorov, Kï̈v. Derž. Univ. Nauk. Zap. 12 (1953).

M 1\%, 1096

Gihman, I. I., On a criterion of fit for discrete random variables, Dopovidi Akad. Nauk Ukrain. RSR 1952, 7 (1952).

M 15, 724

Gihman, I. I., Some limit theorems for conditional distributions, Doklady Akad. Nauk. SSSR 91, 1003 (1953).

M 15, 445

Gihman, I. I., On some limit theorems for conditional distributions and on problems of mathematical statistics connected with them, Ukrain. Mat. Žurnal 5, 413 (1953).

M 15, 722

Gini, C., Alle basi del metodo statistico. Il principio della compensazione degli errori accidentali e la legge dei grande numeri, Metron 14, 173 (1941). M 8, 474

Ginsbourg, G., Sur les conditions suffisantes pour l'unicité des distributions limites, $C$. R. Doklady Acad. Sci. URSS 30, 295 (1941). M 3, 4

Ginsbourg, G., Sur les lois limites des distributions dans les procédés stochastiques, Comm. Inst. Sci. Math. Méc. Univ. Kharkoff 1\%, 65 (1940).

M 3, 4

Ginzburg, G. M., On limit distributions determined by stochastic equations with an infinite set of zeros of the dispersion function, Dokl. Akad. Nauk SSSR 102, 441 (1955).

M 1\%, 166

Ginzburg, G. M., On uniqueness conditions for limit distributions, Izvestiya Akad. Nauk SSSR Ser. Mat. 15, 563 (1951).

M 13, 475

Glivenko, V., Théorie générale des structures, Actualités scient. et industr. No. 652, (Hermann \& Cie Paris, 1938).

Z 22, 243

- Gliwenko, N., Conceptions diverses, Actualités scient. et industr. No. 739, (Hermann \& Cie Paris, 1938).

Z 22, 243

Gnedenko, B., Quelques théorèmes sur l'ensemble des puissances d'une loi de probabilité, Uchenye Zapiski Moskov. Gos. Univ. Matematika 45, 61 (1940).

M 2,228

Gnedenko, B., Limit theorems for the maximal term of a variational series, C.R. Doklady Acad. Sci. URSS 32, 7 (1941).

M 3, 169

Gnedenko, B., On locally stable probability distributions, C. R. Doklady Acad. Sci. URSS 35, 263 (1942).

M 4, 102

Gnedenko, B., Investigation of the growth of homogeneous random processes with independent increments, C. R. Doklady Acad. Sci. URSS 36, 3 (1942).

M 4, 103

Gnedenko, B., Sur la distribution limite du terme maximum d'une série aléatoire, Ann. of Math.44, 423 (1943).

M 5, 41

Gnedenko, B., Sur la croissance des processus stochastiques homogènes à accroissements indépendants, Bull. Acad. Sci. URSS, Sér. Math. \%, 89 (1943).

M 5, 125

Gnedenko, B. V., On the iterated logarithm law for homogeneous random processes with independent increments, C. R. Doklady Acad. Sci. URSS 40, 255 (1943). 
Gnedenko, B. V., Limit theorems for sums of independent random variables, Uspehi Matem. Nauk 10, 115 (1944).

$\mathrm{M} \boldsymbol{\gamma}, 19$ Amer. Math. Soc. Translation No. 45, 82 pp. (1951). [English translation of above reference]

M 12, 619

Gnedenko, B. V., Elements of the theory of distribution functions of random vectors, Uspehi Matem. Nauk 10, 230 (1944).

M $\boldsymbol{\gamma}, 19$

Gnedenko, B. V., On a local limit theorem of the theory of probability, Uspehi Matem. Nauk 3, 187 (1948).

M 10, 132

Gnedenko, B. V., On a local theorem for the region of normal attraction of stable laws, Doklady Akad. Nauk SSSR 66, 325 (1949).

M 10, 720

Gnedenko, B. V., On a local theorem for stable limit distributions, Ukrain. Mat. Žurnal 1, 3 (1949).

M 14, 61

Gnedenko, B. V., On a local limit theorem for identically distributed independent summands, Wiss. Z. Humboldt-Univ. Berlin, Math-Nat. Reihe 3, 287 (1954).

M 16, 494

Gnedenko, B. V., Limit theorems for sums of independent summands and for Markov chains, Ukrain. Mat. Žurnal 6, 5 (1954).

M 17, 978

Gnedenko, B. V., Limit Distributions for sums of independentrandom variables (Addison-Wesley Publishing Co., Cambridge, Mass. 1954). M 16, 52

Gnedenko, B., Sur les lois limites de la théorie des probabilités, C. R. Acad. Sci. URSS, 23, 870 (1939).

Z 22, 245

Gnedenko, B., To the theory of limiting theorems for sums of independent random variables, Bull. Acad. Sci. URSS Sér. Math. 1939, 181 (1939).

M 1, 341

Gnedenko, B. V., On the theory of limit theorems for sums of independent random variables, Bull. Acad. Sci. URSS Sér. Math. 1939, 643 (1939).

M 1, 341

Gnedenko, B. V., On limiting laws of the theory of probability, Doklady Akad. Nauk. SSSR 23, 868 (1939).

M 1, 342

Gnedenko, B. V., Some results on the maximum discrepancy between two empirical distributions, Doklady Akad. Nauk SSSR 8R, 661 (1952).

M 13, 760

Gnedenko, B. V., On some properties of limiting: distributions for normed sums, Ukrain. Mat. Žurnal 1, 3 (1949).

M 13, 958

Gnedenko, B. V., On the role of the maximal summand in the summation of independent random variables, Ukrain. Mat. Žurnal 5, 291 (1953).

M 15, 238

Gnedenko, B. V., A local limit theorem for densities, Doklady Akad. Nauk SSSR 95, 5 (1954).

M 15, 806

Gnedenko, B. V., Some remarks on the papers of O. A. Illyašenko and I. I. Gihman, Dopovidi Akad. Nauk Ukrain. RSR 1952, 10 (1952). M 15, 724

$\checkmark$ Gnedenko, B. V., Some remarks on the theory of domains of attraction of stable distributions, Dopovidi Akad. Nauk Ttkrain. RSR 1950, 275 (1950). $\checkmark$ Gnedenko, B. V., Limit Distributions for Sums of Independent Random Variables (Gosudarstv. Izdat. Tehn.-Teor. Lit., Moscow (1949).

M 12, 839

Translation: (Akadémiai Kiadó, Budapest, 1951).

M 14, 294

Goddard, L. S., The accumulation of chance effects and the Gaussian frequency distribution, Philos. Mag. 36, 428 (1945).

M $\boldsymbol{\gamma}, 311$

Gontcharoff, W., Sur la succession des événements dans une série d'épreuves indépendantes réspondant au schème de Bernoulli, C.R. Doklady Acad. Sci. URSS 38, 283 (1943).

M 5, 124

Gontcharoff, W., Sur la distribution des cycles dans les permutations, C.R. Doklady Acad. Sci. URSS 35, 267 (1942).

M 4, 102

González Dominguez, A., Limit theorems for products of random variables, Univ. Buenos Aires Contrib. CI. Ser. A 1, 1 (1950).

M 14, 186

Gordon, A. N., The restricted problem of the random walk, Philos. Mag. 39, 572 (1948). M 10, 131

Greenwood, J. A., On the probability of attaining a given standard deviation ratio in an infinite series of trials, Ann. Math. Statist. 10, 297 (1939).

M 1, 21

Greville, T. N. E., (See J. A. Greenwood) Ann. Math. Statist. 10, 297 (1939).

Grimsey, A. H. R., On the accumulation of chance effects and the Gaussian frequency distribution, Philos. Mag. 36, 294 (1945).

M $\boldsymbol{\gamma}, 311$

Groshev, A., Sur le domaine d'attraction de la loi de Poisson, Bull. Acad. Sci. URSS Sér. Math. 5, 165 (1941).

M 3, 2

$\checkmark$ Gumbel, E. J., The distribution of the number of exceedances, Ann. Math. Statist. 21, 247 (1950).

M 11, 732

Gyires, B., Über den Grenzwert von Summenverteilungen, C. R. Cong. Math. Hongrois pp. 741-758, Akad. Kiadó, Budapest (1952).

M 14, 1099

Hadwiger, H., Bemerkung zum Problem des Ruins beim Spiele, Mitt. Verein. Schweiz. Versich. Math. 40, 41 (1940).

M 3, 1

Hájek, J., Generalization of an inequality of Kolmogorov, Acta Math. Acad. Sci. Hungar. 6, 281 (1955).

$\mathrm{M} \mathrm{17,} 864$

Haldane, J. B. S., Chance effects and the Gaussian distribution, Philos. Mag. 36, 184 (1945).

M $\boldsymbol{7}, 18$

Halmos, P. R., On a necessary condition for the strong law of large numbers, Ann. of Math . 40, 800 (1939).

M 1, 62

Halmos, P. R., Random alms, Ann. Math. Statist. 15, 182 (1944).

M 6, 5

Hammersley, J. M., An extension of the SlutzkyFréchet theorem, Acta Math. 8\%, 243 (1952).

M 14, 294

Hanš, O., The strong law of large numbers for generalized random variables, Bull. Acad. Polon. Sci. CL. III, 4, 15 (1956).

M 18, 979

Harris, T., (See R. Bellman). Pacific J. Math. 1, 179 (1951). 
Hartman, P., Normal distributions and the law of the iterated logarithm, Amer. J. Math. 63, 584 (1941).

M 3, 2

- Hartman, P., On the spherical approach to the normal distribution law, Amer. J. Math. 62, 759 (1940).

M 2,107

- Hartman, P., On the law of the iterated logarithm, Amer. J. Math. 63, 169 (1941).

M $\boldsymbol{2}, 228$

Haviland, E. K., Asymptotic probability distributions and harmonic curves, Amer. J. Math. 61, 947 (1939).

M 1, 63

Hewitt, E., Arithmetic and limit theorems for a class of random variables, Duke Math. J. 22, 595 (1955).

M 1\%, 754

Hoeffding, W., A combinatorial central limit theorem Ann. Math. Statist. 22, 558 (1951). $\quad$ M 13, 363

Hoeffding, W., The central limit theorem for dependent random variables, Duke Math. J. 15, 773 (1948).

M 10, 200

Hole, N., Note on the statistical analysis of counter data, Ark. Mat. Astr. Fys. 34B, No. 12 (1947).

M 9, 294

Homma, T., On certain limiting distribution, Rep. Statist. Appl. Res. Union Jap. Sci. Eng. 1, 1 (1951).

M 13, 140

Horner, F., A problem on the summation of simple harmonic functions of the same amplitude and frequency but of random phase, Philos. Mag. 3\%, 145 (1946).

М 9, 97

Horton, H. B., A method for obtaining random numbers, Ann. Math. Statist. 19, 81 (1948). M 9, 450

Hsu, C. T., Samples from two bivariate normal populations, Ann. Math. Statist. 12, 279 (1941).

M 3, 174

Hsu, P. L., A lemma on the coefficient of reduction of a sum of independent variates, Acad. Sinica Science Record 4, 197 (1951).

M 16, 53

Hsu, P. L., The approximate distributions of the mean and variance of a sample of independent variables, Ann. Math. Statist. 16, 1 (1945).

M 6, 233

Hsu, P. L., On the approximate distribution of ratios, Ann. Math. Statist. 16, 204 (1945).

M $\%, 18$

Hsu, P. L., Sur un théorème de probabilités dénombrables, C. R. Acad. Sci. Paris 223, 467 (1946).

M 8, 36

Hsu, P. L., Complete convergence and the law of large numbers, Proc. Nat. Acad. Sci. U.S.A. 33, 25 (1947).

M 8, 470

Hunt, G. A., (See P. Erdös) Pacific J. Math. 3, 673 (1953).

Hunt, G. A., (See K. L. Chung) Ann. of Math. 50, 385 (1949).

-Huron, R., Sur une application du schéma d'urnes de Poisson, Ann. Fac. Sci. Univ. Toulouse 1\%, 265 (1954).

M 16, 268

Ikeda, N., Fluctation of sums of independent random variables, Mem. Fac. Sci. Kyusyu Univ. Ser. A. 10, 15 (1956).

M 18, 342

Illyašenko, O. A., On the influence of grouping of empirical data on A. N. Kolmogorov's criteria of fit, Dopovidi Akad. Nauk Ukrain. RSR 1952, 3 (1952).

M 15, 724

Izumi, S., Notes on Fourier analysis. XVI. On the strong law of large numbers and gap series, Tôhoku Math. J. 3, 89 (1951).

M 14, 868

Jacob, M., Sul theorema limite nel calcolo della probabilita, Atti 1, Congr. Un. Mat. Ital. pp. 417420 (1938).

$\mathrm{Z} \mathbf{2 0}, 41$

Juncosa, M. L., The asymptotic behavior of the minimum in a sequence of random variables, Duke Math. J. 16, 609 (1949).

M 11, 375

$\checkmark$ Kac, M., (See P. Erdös) Amer. J. Math. 62, 738 $(1940)$.

$\checkmark$ Kac, M., (See P. Erdös) Bull. Amer. Math. Soc. 52, 292 (1946).

Kac, M., (See D. A. Darling) Trans. Amer. Math. Soc. 84, 444 (1957).

Kac, M., (See K. L. Chung) Mem. Amer. Math. Soc. No. 6 (1951).

Kac, M., Quelques remarques sur les fonctions indépendentes, C. R. Acad. Sci. Paris 202, 1963 (1936).

$\mathrm{Z}$ 14, 222

Kac, M., On the distribution of values of sums of the type $\Sigma \mathrm{f}\left(2^{\mathrm{k}} \mathrm{t}\right)$, Ann. of Math. $\mathbf{4 7}, 33$ (1946). M $\boldsymbol{g}, 436$

Kac, M., On the average of a certain Wiener functional and a related limit theorem in calculus of probability, Trans. Amer. Math. Soc. 59, 401 (1946).

M 8,37

Kac, M., On deviations between theoretical and empirical distributions, Proc. Nat. Acad. Sci. U.S.A. 35, 252 (1949). M 10, 614

Kac, M., Sur les fonctions indépendantes. II. La loi exponentielle; la divergence de séries, Studia Math. 6, 59 (1936).

Z 15, 218

- Kac, M., Sur les fonctions indépendantes. III. Le mouvement brownien; la loi de Maxwell, Studia Math. 6, 89 (1936).

Z 15, 218

$\checkmark$ Kac, M. (See K. L. Chung) Proc. Amer. Math. Soc. 4, 560 (1953).

Kallianpur, G., On an ergodic property of a certain class of Markov processes, Proc. Amer. Math. Soc. 6, 159 (1955).

M 16, 1035

$\checkmark$ Kallianpur, G., The sequence of sums of independent random variables, Duke Math. J. 21, 285 (1954).

M 16, 52

van Kampen, E. R., Infinite product measures and infinite convolutions, Amer.J. Math. 62, 417 (1940).

M 1, 209

van Kampen, E. R., A limit theorem for probability distributions on lattices, Amer. J. Math. 61, 965 (1939).

M 1, 635

Kanellos, S. G., Statistical test of an observation on logarithmic tables by a method of Pearson, Bull. Soc. Math. Grèce 23, 127 (1948).

M 10, 131

Kanellos, S. G., On the probability of a sum of infinitely many events, Bull. Soc. Math. Grèce $\mathbf{2 5 ,} 104$ (1951).

M 12, 722

Kanellos, S. G., On the "comparative frequency" of an event, Bull. Soc. Math. Grèce $\mathbf{2 \%}, 25$ (1953).

M 15, 444

Kanellos, S. G., On a theorem of N. Kritikos, Bull. Soc. Math. Grèce 2\%, 111 (1953).

M 15, 444 
Kaplansky, I., The asymptotic distribution of runs of consecutive elements, Ann. Math. Statist. 16, 200 (1945).

M $\boldsymbol{\gamma}, 208$

Karlin, S., On the renewal equation, Pacific J. Math. 5, 229 (1955).

M 1\%, 49

Kawata, T., Typical functions of sums of non-negative independent random variables, Kōdai Math. Sem. Rep. 8, 13 (1956).

M 18, 519

- Kawata, T., On the strong law of large numbers, Kōdai Math. Sem. Rep. 1951, 78 (1951).

M 13, 567

Kawata, T., A renewal theorem, J. Math. Soc. Japan 8, 118 (1956).

M 18, 75

Kawata, T., On the strong law of large numbers, Proc. Imp. Acad. Tokyo 16, 109 (1940). M 1, 340

Kawata, T., On the relative stability of sums of positive random variables, Kōdai Math. Sem. Rep. 1950, 113 (1950).

M 12, 722

Kawata, T., Limit distributions of single order statistics, Rep. Statist. Appl. Res. Union Jap. Sci. Eng. 1, 4 (1951).

M 13, 142

Kawata, T., On the central limit theorem and the moment generating function, Rep. Statist. Appl. Res. Union Jap. Sci. Eng. 1, 6 (1951). M 14, 294

Kazansky, A., Sur un cas du théorème de limite de la théorie des probabilités, Ann. Inst. Mines Leningrade 8, 236 (1934).

$\mathrm{Z} \mathbf{1 1}, 125$

Keller, L., Über die Ausdehnung der Grenzwertsätze der Wahrscheinlichkeitsrechnung auf Integrale und Mittelwerte von Funktionen eines stetigen Argumentes, Trans. Centr. Geophys. Observ. 4, 5 (1935).

Z 15, 168

-Kendall, D. G., (See K. S. Rao) Biometrika 3\%, $224(1950)$.

- Kesten, H., Some elementary proofs in renewal theory with applications to waiting times, Math. Centrum Amsterdam Rep. S 203, (1956).

M 18, 156

Khintchine, A., Sul dominio di attrazione della legge di Gauss, Giorn. 1st. Ital. Attuari 6, 378 (1935).

Z 13, 29

Khintchine, A., Su una legge dei grandi numeri generalizzata, Giorn. 1st. Ital. Attuari y, 365 (1936).

Z 15, 167

Khintchine, A., Zur Theorie der unbeschränkt teilbaren Verteilungsgesetze, Rec. Math. Moscou $\mathbf{2 ,} 79$ (1937).

Z 16, 410

Khintchine, A., Valeurs moyennes des fonctions sommatoires dans la mécanique statistique, $C . R$. Doklady Acad. Sci. URSS 33, 442 (1941).

M 5, 167

Khintchine, A., Sur la correlation intermoléculaire, C. R. Doklady Acad. Sci. URSS 33, 482 (1941).

M 5, 168

Khintchine, A., Mathematical Principles of Statistical Mechanics (OGIZ, Moscow-Leningrad, 1943).

M 8, 187

Khintchine, A., Limit theorems for sums of positive random quantities, Ukrain. Mat. Žurnal 2,3 (1950).

M 14, 60

Khintchine, A., Mathematical foundations of quantum statistics (Gosudarstv. Izdat. Tehn.-Teor. Lit., Moscow, 1951).

M 13, 894

Khintchine, A., On some general theorems of statistical physics, Trudy Mat. Inst. Steklov, 38, 345 (1951).

M 13, 895

Kimball, B. F., On the asymptotic distribution of the sum of powers of unit frequency differences, Ann. Math. Statist. 21, 263 (1950). M 11, 673

Kimball, B. F., Note on asymptotic value of probability distribution of sum of random variables which are greater than a set of arbitrarily chosen numbers, Ann. Math. Statist. 15, 423 (1944).

M 6, 233

Kimme, E. G., On the convergence of sequences of stochastic processes, Trans. Amer. Math. Soc. 84, 208 (1957).

M 18, 770

Kitagawa, T., The limit theorems of the stochastic contagious processes, Mem. Fac. Sci. Kyūsyū Imp. Univ. A 1, 167 (1941).

M 2,230

Kitagawa, T., The weakly contagious discrete stochastic process, Mem. Fac. Sci. Kyūsyū Imp. Univ. A \%, 37 (1941).

M 3, 170

Kitagawa, T., The weakly contagious stochastic process which depends upon the Gaussian distribution, Mem. Fac. Sci. Kyūsyū Imp. Univ. A 2 , 27 (1941).

M 3,170

Kloss, B. M., Limiting distributions of sums of independent random variables taking values from a bicompact group, Dokl. Akad. Nauk SSSR 109, 453 (1956).

M 18, 680

Kolmogorov, A. N., (See B. V. Gnedenko) Akadémiai Kiadó, Budapest (1951).

Kolmogorov, A. N., The solution of a problem in the theory of probability, connected with the question of the mechanism of the formation of strata, Doklady Akad. Nauk SSSR 65, 793 (1949).

M 10, 720

Kolmogorov, A. N., Some work of recent years in the field of limit theorems in the theory of probability, Acad. Repub. Pop. Romîne. An. Rom.-Sov. Mat.-Fiz. 8, 5 (1954).

M 16, 378

Kolmogorov, A. N., A theorem on the convergence of conditional mathematical expectations and some of its applications, C.R. 1st Congr. Math. Hongrois, pp. 367-386. (Akadémiai Kiadó, Budapest, $1952)$.

M 14, 1099 Kolmogoroff, A. N., Zufällige Funktionen und Grenzverteilungssätze, Ber. ü. Wahrsch. Stat. pp. 113-126 (Verlag Wissenschaften, Berlin, 1956).

M 18, 519

Kolmogoroff, A. N., (See B. V. Gnedenko) (Addison-Wesley Publishing Co., Cambridge, Mass. 1954).

Koopman, B. O., Necessary and sufficient conditions for Poisson's distribution, Proc. Amer. Math. Soc. 1, $813(1950)$.

M 12, 424

Koopman, B. O., A law of small numbers in Markoff chains, Trans. Amer. Math. Soc. 70, 277 (1951).

M 14, 1100

Korolyuk, V. S., Asymptotic expansions for the criteria of fit of A. N. Kolmogorov and N. V. 
Smirnov, Izv. Akad. Nauk SSSR Ser. Mat. 19, $103(1955)$.

M 16, 839

Korolyuk, V. S., Asymptotic expansions for distributions of maximum-deviations in the scheme of Bernoulli, Dokl. Akad. Nauk SSSR 108, 183 (1956).

M 18, 241

- Korolyuk, V. S., (See B. V. Gnedenko) Dopovidi Akad. Nauk Ukrain RSR 1950, 275 (1950).

Kosambi, D. D., The law of large numbers, Math. Student 14, 14 (1946)

М 9, 360

Kozakiewicz, W., Sur les fonctions caractéristiques et leur application aux théorémes limites du calcul des probabilités, Ann. Soc. Polon. Math. 13, 24 (1935).

$Z \mathbf{1 4}, 121$

Kozakiewicz, W., Sur la convergence presque certaine, Bull. Sci. Math. 64, 121 (1940). M 4, 16

Kozakiewicz, W., On the necessary and sufficeint conditions for the convergence of a sequence of moment generating functions, Ann. Math. Statist. 22, 478 (1951).

M 13, 258

Krysicki, W., The limit theorem on terms of higher order on Baves problem, Prace Mat. 1, 93 (1955).

M 18, 634

Kudela, Fr., La démonstration du second théoréme limite du calcul de probabilité par la méthode de Cauchy-Lévy reposant sur la fonction caractéristique, Aktuár. Vĕdy 6, 155 (1937). Z 1\%, 175 Kudô, A., On the strong law of large numbers, Mem. Fac. Sci. Kyūsyū Univ. A. '\%, 69 (1953).

M 15, 542

Kunisawa, K., Mean concentration function and the law of large numbers, Proc. Imp. Acad. Tokyo 20, 627 (1944).

M \%, 312

Kunisawa, K., On an analytical method in the theory of independent random variables, Ann. Inst. Statist. Math. Tokyo 1, 1 (1949). M 11, 255

Kunisawa, K., Limit theorems in probability theory, (Chûbunkan, Tokyo 1949).

M 15, 42

- Kunisawa, K., Some properties of infinitely divisible laws, Rep. Statist. Appl. Res. Union Jap. Sci. Eng. 1, 22 (1951).

M 14, 294

Lebedinceva, O. K., On limiting distributions for normalized sums of independent random quanties, Dopovidi Akad. Nauk Ukrain. RSR 1955, 12 (1955)

M 1\%, 754

Ledermann, W., On the asymptotic probability distribution for certain Markoff processes, Proc. Cambrideg Philos. Soc. 46, 581 (1950). M 12, 269

Lévy, P., Les processus fortement continus et la loi de Laplace, C. R. Acad. Sci. Paris 222, 839 (1946).

M $\boldsymbol{\gamma}, 459$

Lévy, P., Remarques sur un théorème de M. Émile Borel, C. R. Acad. Sci. Paris 225, 918 (1947).

M 9, 292

Lévy, P., Convergence des séries aléatoires et loi normale, C. R. Acad. Sci. Paris 234, 2422 (1952).

M 14, 61

Lévy P., Loi faible et loi forte des grands nombres, C. R. Acad. Sci. Paris 235, 1186 (1952)

M 14, 485

Lévy, P., Loi faible et loi forte des grands nombres, Bull. Sci. Math. \%\%, 9 (1953).
Lévy, P., Le dernier manuscrit inédit de W. Doeblin, Bull. Sci. Math. 80,61 (1956).

M 18, 519

Lévy, P., Le caractère universel de la courbe du mouvement brownien et la loi du logarithme itéré, Rend. Circ. Mat. Palermo 4, 337 (1956).

M 1\%, 1096

Lévy, P., Sur un théorème de M. Khintchine, Bull. Sci. Math. II. 55, 145 (1931). Z 2, 43

Lévy, P., Propriétés asymptotiques des sommes de variables aléatoires indépendantes ou enchaînées, J. Math. Pures. Appl., IX 14, 347 (1935). Z 13, 28 Lévy, P., Détermination générale des lois limites, C. R. Acad. Sci., Paris $\mathbf{2 0 3 ,} 698$ (1936). Z 15, 72 Lévy, P., Théorie de l'addition des variables aléatoires, (Gauthier-Villars, Paris, 1937).

Z 16, 170

Lévy, P., Extensions stochastiques des notions de série, d'intégrale et d'aire, C.R.Acad. Sci. Paris $\mathbf{2 0 9}$, 591 (1939).

M 1, 62

Lévy, P., Intégrales stochastiques, Ann. Univ. Lyon Sect. A 4, 67 (1941).

M 8, 37

Linnik, U. V., On the accuracy of the approximation to the Gauss distribution by sums of independent variables, Bull. Acad. Sci. URSS Sér. Math. 11, 111 (1947)

M 8, 591

Linnik, U. V., On the accuracy of the approximation of the Gaussian distribution by sums of independent random variables, $C$. R. Doklady Acad. Sci. URSS 55, 571 (1947).

M 8, 591

Linnik, Y. V., On nonstationary Markov chains, Doklady Akad. Nauk SSSR 60,21 (1948).

M 9, 520

Linnik, Y. V., Multiple integrals and local laws for inhomogeneous Markov chains, Izvestiya Akad. Nauk SSSR Ser. Mat. 13, 533 (1949). M 11, 606

Lipschutz, M., On strong bounds for sums of independent random variables which tend to a stable distribution, Trans. Amer. Math. Soc. 81, 135 (1956)

M 18,979

Lipschutz, M., Generalization of a theorem of Chung and Feller, Proc. Amer. Math. Soc. 3, 659 (1952).

M 14, 662

Lipschutz, M., On strong laws for certain types of events connected with sums of independent random variables, Ann. of Math. 5\%, 318 (1953).

M 15, 43

Loève, M., Sur les systèmes d'événements; application à deux théorèmes classiques, $C . R$. Acad. Sci. Paris 212, 261 (1941).

M 3, 3

Loève, M., La loi forte des grands nombres pour des variables aléatoires liées, C.R. Acad. Sci. Paris 212, 1121 (1941).

M 5, 207

Loève, M., La tendance centrale des sommes de variables aléatoires liées, C.R. Acad. Sci. Paris 213, 9 (1941).

M 5, 207

Loève, M., Nouvelles classes de lois limites, Bull. Soc. Math. France 73, 107 (1945).

M $\boldsymbol{\gamma}, 209$

Loève, M., Etude asymptotique des sommes de variables aléatores liées, J. Math. Pures Appl. 24, 249 (1945).

M $\boldsymbol{\gamma}, 458$

Loève, M., Sur l'équivalence asymptotique des lois, C. R. Acad. Sci. Paris 22\%, 1335 (1948).

M 10, 385 
Loève, M., On the "central" probability problem, Proc. Nat. Acad. Sci. U.S.A. 35, 328 (1949).

M 11, 188

Loève, M., Remarques sur la convergence presque sûre, C. R. Acad. Sci. Paris 230, 52 (1950).

M 11, 375

Loève, M., Lois pondérées et le problème limite central, C. R. Acad. Sci. Paris 231, 26 (1950).

M 12, 34

Loève, M., Fundamental limit theorems of probability theory, Ann. Math. Statist. 21, 321 (1950).

M 12, 114

Loève, M., On sets of probability laws and their limit elements, Univ. California Publ. Statist. 1, 53 (1950).

M 12, 425

Loève, M., On almost sure convergence, Proc. Second Symp. Math. Stat. \& Prob., pp. 279-303, (Univ. Cal. Press, Berkeley 1951). M 13, 853

Loève, M., Ranking limit problem, Proc. Third Symp. Math. Stat. \& Prob., Vol. II, pp. 17n-194, (Univ. Cal. Press, Berkeley 1956). M 18, 942

Loève, M., Termes variationnels dans le modèle limite central, C. R. Acad. Sci. Paris 240, 722 (1955).

M 16, 600

Loève, M., Relations entre lois limites, $C$. R. Acad. Sci. Paris 239, 1585 (1954).

M 16, 494

Loève, M., Nouvelles classes de lois limites, C. R. Acad. Sci. Paris 210, 202 (1940). $\quad$ M 1, 246

Lord, F. M., Estimation of parameters from incomplete data, J. Amer. Statist. Assoc. 50, 870 (1955).

M 1\%, 169

Lourier, A., La loi directe, inverse et absolue des grands nombres, C. R. Doklady Acad. Sci. URSS 49, 546 (1945).

M 8, 36

Luré, A. L., On an inverse Bernoulli theorem, Doklady Akad. Nauk SSSR 50, 45 (1945).

M 14, 567

Madow, W. G., Limiting distributions of quadratic and bilinear forms, Ann. Math. Statist. 11, 125 (1940).

M 1, 341

Makabe, H., On the approximation to some limiting distributions, Kōdai Math. Sem. Rep. 8, 31 (1956).

M 18, 423

Manevič, D. V., On a local limit theorem for stationary Markov chains, Dokl. Akad. Nauk Üzbek. SSR No. y, 5 (1953).

M 17, 978

- Mann, H. B., On the statistical treatment of linear stochastic difference equations, Econometrica 11, 173 (1943).

M 5, 129

Mann, H. B. (See A. P.Calderon), Sankhyā 12, 347 (1953).

Mann, H. B., On stochastic limit and order relationships, Ann. Math. Statis. 14, 217 (1943). M 5, 125

Marcinkiewicz, J., Sur les fonctions indépendantes. II, Fundam. Math. 30, 349 (1938).

Z 18, 319

Marcinkiewicz, J., Quelques théorèmes de la théorie des probabilités, Bull. Sém. Math. Univ. Wilno 2 22 (1939).

M 1, 21

Marcinkiewicz, J., Remarque sur la loi du logarithme itéré, Fundam. Math. 29, 215 (1937).

Z 18, 32
Maret, A. De la fonction d'événement d'un ensemble ouvert variable, Mitt. Verein. Schweiz. Versich. -Math 4\%, 321 (1947).

M 9, 292

Mark, A. M. Some probability limit theorems, Bull. Amer. Math. Soc. 55, 885 (1949). $\quad$ M 11, 189

Marsaglia, G., Iterated limits and the central limit theorem for dependent variables, Proc. Amer. Math. Soc. 5, 987 (1954).

M 16, 494

Marušin, M. N., Proof of S. N. Bernšteřn's generalized fundamental lemma for sums of almost independent quantities satisfying Lindberg's condition, Doklady Akad. Nauk SSSR 90, 21 (1953).

M 14, 1099

Marušin, M. N., On necessary and sufficient conditions for applicability of a limit theorem of order $\mathrm{p}<2$, Doklady Akad. Nauk SSSR 90, 727 (1953).

M 15, 140

Maruyama, G., Fourier analytic treatment of some problems on the sums of random variables, Nat. Sci. Rep. Ochanomizu Univ. 6, 7 (1955).

M 18, 341

Maruyama, G., On the Poisson distribution derived from independent random walks, Nat. Sci. Rep. Ochanomizu Univ. 6, 1 (1955). M 18, 341

Maruyama, G., Note on the are sine law in the theory of probability, Nat. Sci. Rep. Ochanomizu Univ. 2, 25 (1951).

M 14, 294

- Maruyama, G. (See K. Kunisawa), Rep. Statist. Appl. Res. Union Jap. Sci. Eng. 1, 22 (1951).

Masuyama, M., The Bienaymé-Tchebycheff inequality for Hermitic tensors, Proc. Phys.-Math. Soc. Japan 24, 409 (1942).

M $\boldsymbol{g}, 310$

Matsuyama, N., The law of the iterated logarithm for dependent random variables, Sci. Rep. Kanazawa Univ. 4, 177 (1956).

M 18, 680

Meǐzler, D. G., On a problem of B. V. Gnedenko, Ukrain. Mat. Zurnal 1, 67 (1949). $\quad$ M 14, 186

Meǐzler, D. G., On the limit distribution of the maximal term of a variational series, Dopovidi Akad. Nauk Ukrain. RSR 1950, 3 (1950).

M 13, 663

Meľzler, D. G., On partial limit distributions for the maximal term of a variational series, L'vov. Politehn. Inst. Nauč. Zap. 30, Ser. Fiz.-Mat. No. 1, 24 (1955).

M 1\%, 864

Meǐzler, D. G., A multidimensional local limit theorem of the theory of probability, Doklady Akad. Nauk SSSR 60, 1127 (1948). M 10, 132

- Meǐzler, D. G., On a many dimensional local limit theorem of the theory of probability, Ukrain. Mat. Žurnal 1, 9 (1949).

M 14, 61

Méric, J., (See R. Huron), Ann. Fac. Sci. Univ. Toulouse 1\%, 265 (1954).

Mihoc, G., Sur les lois-limites des variables liées en chaîne, Bul. Fac. Sti. Cernăuti 10, 1 (1936).

Z 16, 128

- Mihoc, G., (See O. Onicescu), Giorn. 1st. Ital. Attuari y, 54 (1936).

Mihoc, G., (See O. Onicescu), Bull. Math. Phys. Bucarest 8, 61 (1937).

Milicer-Grużewska, H., L’arithmétique des variables aléatoires, Cahiers Rhodan. 6, 9 (1954). M 1\%, 166 
Milicer-Grużewska, H., The coefficient of correlation a posteriori of equivalent variables, Soc. Sci. Lett. Varsovie C. R. Cl. III. Sci. Math. Phys. 39, 3 (1947).

M 11, 374

Milicer-Grużewska, H., Sulla legge limite delle variabili casuali equivalenti, Atti. Accad. Naz. Lincei., Fis.-Mat. 2, 25 (1948).

M 11, 118

Milicer-Grużewska, H., On the law of probability and the characteristic function of the standardized sum of equivalent variables, Soc. Sci. Lett. Varsovie C. R. Cl. III, Sci. Math. Phys. 42, 99 (1950).

M 13, 959

von Misès, R., Les sommes et les fonctions de variables aléatoires, Actual. Sci. Industr. No. 736, (Hermann \& Cie, Paris (1938).

Z 22, 241

von Misès, R., Deux nouveaux théorèmes de limite dans le calcul des probabilities, Rev. Fac. Sci. Univ. Istanbul 1, 61 (1935). Z 12, 266

von Misès, R., Die Gesetze der groben Zahl für statistische Funktionen, Mh. Math. Phys. 43, 105 (1936).

$\mathrm{Z} \mathrm{14,} 27$

von Misès, R., Les lois de probabilité pour les fonctions statistiques, Ann. Inst. H. Poincaré 6, 185 (1936).

$\mathrm{Z} \mathrm{16,} 312$

Mood, A. M., The distribution theory of runs, Ann. Math. Statist. 11, 367 (1940).

M $\boldsymbol{2}, 228$

Moran, P. A. P., Random associations on a lattice, Proc. Cambridge Philos. Soc. 43, 321 (1947).

M 8, 592

Moran, P. A. P., A class of complex Markoff chains, Quart. J. Math. Oxford Ser. 19, 140 (1948).

M 10, 132

Moran, P. A. P., The statistical distribution of the length of a rubber molecule, Proc. Cambridge Philos. Soc. 44, 342 (1948).

M 10, 132

Morgenthaler, G. W., A central limit theorem for uniformly bounded orthonormal systems, Trans. Amer. Math. Soc. 79, 281 (1955).

M 1\%, 49

Morimura, H., On a renewal theorem, Kōdai Math. Sem. Rep. 8, 125 (1956).

M 18, 942

- Morimura, H., (See H. Makabe), Kōdai Math. Sem. Rep. 8, 31 (1956).

Mourier, E., Lois des grands nombres et théorie ergodique, C. R. Acad. Sci. Paris 232, 923 (1951).

M 12, 616

$\checkmark$ Mourier, E., (See R. Fortet), Bull. Sci. Math. 78, 14 (1954).

- Mourier, E., (See R. Fortet), C. R. Acad. Sci. Paris 234, 699 (1952).

- Mourier, E., (See R. Fortet), C. R. Acad. Sci. Paris 236, 1739 (1953).

$\checkmark$ Mourier, E., (See R. Fortet), C. R. Acad. Sci. Paris \%3\%, 18 (1953).

- Mourier, E., (See R. Fortet), Ann. Sci. École Norm. Sup. \%0, 267 (1953).

Mourier, E., (See R. Fortet), C. R. Acad. Sci. Paris 238, 1557 (1954).

Mulholland, H. P., An inequality related to the central limit theorem on probabilities, J. London Math. Soc. 28, 360 (1953).

M 14, 993

Müller, M., Zur Herleitung des Gausschen Fehlergesetzes aus der Hypothese der Elementarfehler,
Jber. Deutsch. Math. Verein. 58, 79 (1956).

M 1\%, 1095

Mycielski, J., On the distances between signals in the non-homogeneous Poisson stochastic process, Studia Math. 15, 300 (1956).

M 18, 520

Nakagami, M., On the resultant intensity of a number of vibrations whose phase are at random, Nippon Elec. Commun. Engrg., No. 19, $129(1940)$

M 2,229

Nash, S. W., An extension of the Borel-Cantelli lemma, Ann. Math. Statist. 25, 165 (1954).

M 15, 883

Neyman, J., Sur la loi probabilité limite d'un système de variables aléatoires, $C . R$. Acad. Sci. Paris 203, 1211 (1936).

Z 15, 219

Norris, N., The standard errors of the geometric and harmonic means and their application to index numbers, Ann. Math. Statist. 11, 445 (1940).

M 2, 228

Núnez Bazalar, T., On the law of large numbers of the theory of probability, Revista Ci., Lima 4\%, 601 (1945).

M 8, 36

Obrechkoff, N., Sur quelques lois asymptotiques de probabilités et sur les solutions bornées de quelques équations intégrales singulières et des équations linéaires à un nombre infini des inconnues, $A n n u$ aire Univ. Sofia. Fac. Phys.-Math., Livre 1, 43, 269 (1947).

M 12, 269

Obrechkoff, N., Sur quelques lois asymptotiques de probabilités, Annuaire Univ. Sofia. Fac. Sci. Livre 1, 44, 201 (1948).

M 12, 269

Obreschkoff, N., Über einige asymptotische Formeln in der Wahrscheinlichkeitsrechnung, Ber. ü. Wahrsch. \& Stat. pp. 37-42 (Verlag Wissenschaften, Berlin, 1956).

M 18, 424

Ohno, M. (See M. Nakagami). Nippon Elec. Commun. Engrg., No. 19, 129 (1940).

Onicescu, O., Sopra le leggi-limite delle probabilità, Giorn. 1st Ital. Attuari \%, 54 (1936). Z Z 13, 273 - Onicescu, O., Sur une généralisation de l'urne de Bernoulli, Bull. Math. Phys. École Polytechn. Bucarest 8, 61 (1937).

Z 22, 369

Orts, J. M., The Legendre polynomials and the scheme of repeated trials, Revista Mat. Hisp.Amer. 1, 198 (1941).

M $\boldsymbol{\gamma}, 128$

Orts, J. M., Convergence of some mean values, Revista Mat. Hisp.-Amer. 4, 127 (1944). M 6, 232 Orts, J. M., On some sequences of random variables, Revista Mat. Hisp.-Amer. 5, 53 (1945). M \%, 18 Ostrowski, A., Sur la formule de Moivre-Laplace, C. R. Acad. Sci. Paris 223, 1090 (1946).

M 8, 280

Ottaviani, G., La loi uniforme des grands nombres dans l'esprit de la théorie classique des probabilités. Considérations relatives au concept de nombre normal et aux liens avec la théorie de M. de Misès, Coll. Int. Centre Nat. Rech. Sci. 13, 11, Paris (1949)

M 11, 375

Parasyuk, O. S. (See D. G. Meǐzler),

Doklady Akad. Nauk SSSR 60, 1127 (1948). 
Parasyuk, O. S. (See D. G. Mè̌zler), Ukrain Mat. Zurnal 1, 9 (1949).

Parker, J. B., The accumulation of chance effects and the Gaussian frequency distribution, Philos. Mag. 38, 681 (1947).

M 9, 360

Parzen, E., A central limit theorem for multilinear stochastic processes, Ann. Math. Statist. 88, 252 (1957).

M 18, 944

Parzen, E., On uniform convergence of families of sequences of random variables, Univ. California Publ. Statist. \%, 23 (1954).

M 15, 806

Paulson, E., Some limiting distributions related to the sum of a random number of random variables, Proc. Amer. Math. Soc. 1, 625 (1950). M 12, 425

Persidskij, K., Über das Gesetz der groben Zahlen, C. R. Acad. Sci. URSS, 18, 81 (1938). Z 18, 411

Petrov, V. V., On precise estimates in limit theorems, Dokl. Akad. Nauk. SSSR 104, 180 (1955).

M 1\%, 753

Petrov, V. V., On precise estimates in limit theorems, Vestnik Leningrad. Univ. 10, 57 (1955).

M 1\%, 753

Petrov, V. V., Extension of Cramér's limit theorem to non-identically distributed independent quantities, Vestnik Leningrad. Univ. No. 8, 13 (1953).

M 17, 979

Petrov, V. V., Generalization of Cramér's limit theorem, Uspehi Matem. Nauk 9, 195 (1954).

M 16, 378

Pitt, H. R., A special class of homogeneous random processes, J. London Math. Soc. 15, 247 (1940).

M 2,231

Plessner, A., Über das Gesetz der groben Zahlen, Rec. Math. Moscou 1, 165 (1936). Z 14, 168

- Pollard. H. (See K. L. Chung), Proc. Amer. Math. Soc. 3, 303 (1952).

Pólya, G., Sur une généralisation d'un problème élémentaire classique, importante dans l'inspection des produits industriels, C.R. Acad. Sci. Paris 22?, 1422 (1946).

M 8, 37

Pompilj, G., Sulla media geometrica e sopra un indice di mutabilità calcolati mediante un campione, Mem.Soc. Ital. Sci. 26, 299 (1947). M 11, 118

Postnikov, A. G., Additive problems with a growing number of terms, Dokl. Akad. Nauk SSSR 108, 392 (1956).

M 18, 468

Postnikov, A. G., On an application of the centrallimit theorem of the theory of probability, Uspehi Mat. Nauk 10, 147 (1955).

M 16,1002

- Prékopa, A., On the limiting distribution of sums of independent random variables in bicompact commutative topological groups, Acta Math. Acad. Sci. Hungar. 8, 11 (1956).

M 18, 25

- Prochorow J., (See A. Kolmogoroff), Ber. ü.Wahrsch. \& Stat. pp. 113-126 (Verlag Wissenschaften, Berlin, 1956).

Prohorov, Y. V., Convergence of random processes and limit theorems in probability theory, Teor. Veroyatnost. i Primenen. 1, 177 (1956) M 18, 943

Prohorov, Y. V., On sums of identically distributed random quantities, Dokl. Akad. Nauk SSSR 105, $645(1955)$.
Prohorov, Y. V., On a local limit theorem for lattice distributions, Dokl. Akad. Nauk SSSR 98, 535 (1954).

M 16, 494

Prohorov, Y. V., On the strong law of large numbers, Doklady Akad. Nauk SSSR 69, 607 (1949).

M 11, 375

Prohorov, Y. V., On the strong law of large numbers, Izvestiya Akad. Nauk SSSR Ser. Mat. 14, 523 (1950).

M 12, 425

Prohorov, Y. V., Some refinements of Lyapunov's theorem, Izvestiya Akad. Nauk SSSR Ser. Mat. 16, 281 (1952).

M 14, 187

Prohorov, Y. V., Asymptotic behavior of the binomial distribution, Uspehi Matem. Nauk 8, 135 (1953).

M 15, 138

Raikov, D., On a connection between the central limit-law of the theory of probability and the law of great numbers, Bull. Acad. Sci. URSS Ser. Math. 3, 323 (1938).

Z 19, 224

Raja Rao S. (See P. Bose), Science and Culture 9, 402 (1944).

Rajchman, A., Das starke Gesetz der groben Zahlen, Mathesis Polska 6, 145 (1931). Z 3, 355

Ranulac, B., Sur la dérivabilité de certaines fonctions représentées par une intégrale. C.R.Acad. Sci., Paris 204, 946 (1937).

$\mathrm{Z} \mathbf{1 6}, 128$

- Rao, K. S., On the generalized second limit-theorem in the calculus of probabilities, Biometrika 3\%, 224 (1950).

M 12, 425

Reissman, G., Betrachtungen zu einem scheinbaren Widerspruch zwischen Fehlergesetz und Fehlerfortpflanzungsgesetz, Wiss. Z. Tech. Hochsch. Dresden 4, 597 (1955).

M 1\%, 169

- Rényi, A. (See J. Hajek), Acta Math. Acad. Sci. Hungar. 6, 281 (1955)

- Rényi, A. (See A. Prékopa), Acta Math. Acad. Sci. Hungar. \%, 11 (1956).

Rényi, A., Simple proof of a theorem of Borel and of the law of the iterated logarithm, Mat. Tidsskr. B. 1948, 41 (1948).

M 10, 384

Rényi, A., Contributions to the theory of independent random variables, Acta Math. Sci. Hungar. 1,99 (1950).

M 12, 619

Rényi, A., On a new generalization of the central limit theorem of probability theory, Magyar Tud. Akad. Mat. Fiz. Oszt. Közleményei 1, 351 (1951).

M 14, 60

Riebesell, P., Neue deutsche Forschungen über das Gesetz der grossen Zahl, Bl. Versich--Math. 5, 68 (1940).

M 2,107

Risser, R., Note relative aux tirages contagieux, Assoc. Actuair. Belges. Bull. 55, 25 (1949).

M 11, 605

Rivkind, Y. I., Limit theorem of probability theory on compact topological groups, Grodnenskŭr Gos. Ped. Inst. Uč. Zap. 1, 51 (1955).

M 18, 680

- Robbins, H. (See C. Derman), Proc. Nat. Acad. Sci. U.S.A. 41, 586 (1955).

Robbins, H., On the (C,1) summability of certain random sequences, Bull. Amer. Math. Soc. 52, 699 (1946). 
Robbins, H., On the asymptotic distribution of the sum of a random number of random variables, Proc. Nat. Acad. Sci. U.S.A. 34, 162 (1948).

M 9, 450

Robbins, H., The asymptotic distribution of the sum of a random number of random variables, Bull. Amer. Math. Soc. 54, 1151 (1948).

M 10, 385

Robbins, H., A note on gambling systems and birth statistics, Amer. Math. Monthly 59, 685 (1952).

M 14, 485

Robbins, H., On the equidistribution of sums of independent random variables, Proc. Amer. Math. Soc. 4, 786 (1953).

M 15, 139

- Robbins, H. (See P. L. Hsu.) Proc. Nat. Acad. Sci.U.S.A. 33, 25 (1947).

- Robbins, H. (See G. Kallianpur.) Duke Math. J. 21, 285 (1954).

- Robbins, H. (See W. Hoeffding.) Duke Math. J. 15, 773 (1948).

Rodgers, E., Probable error for Poisson distributions, Phys. Rev. 5y, 735 (1940).

M 1, 246

Romanosvkiǔ, V. I., On applications of infinite matrices to the theory of probability, Dokl. Akad. Nauk Ǔzbek. SSR No. 9, 3 (1953). M 1\%, 980

Romanovskiǔ, V. I., On limiting distributions for stochastic processes with discrete time parameter, Acta Univ. Asiae Mediae. 4, 25 (1945).

M 11, 189

Rosenblatt, A., On the law of large numbers in the theory of probability, Publ. Inst. Mat. Univ. Nac. Litoral ?, 141 (1940).

M 3, 2

Rosenblatt, A., Sur les théorèmes des grands nombres dans la théorie de la probabilité, Actas Acad. Ci. Lima 3, 152 (1940).

M 4, 16

Rosenblatt, A., On the strong law of large numbers, Actas Acad. Ci. Lima 8, 7 (1945).

M 8, 36

Rosenblatt, M., A central limit theorem and a strong mixing condition, Proc. Nat. Acad. Sci. U.S.A. 4\%, 43 (1956).

M 1\%, 635

Rosenblatt, M., On the oscillation of sums of random variables, Trans. Amer. Math. Soc. 9\%, 165 (1952).

M 13, 567

Rosenblatt, M., The behavior at zero of the characteristic function of a random variable, Proc. Amer. Math. Soc. 3, 498 (1952).

M 13, 958

Rosenblatt, M., Limit theorems associated with variants of the von Mises statistic, Ann. Math. Statist. 23, 617 (1952).

M 14, 665

- Rosenblatt, M. (See J. R. Blum.) Duke Math. J. 24, 73 (1957).

- Rosenblatt, M. (See J. R. Blum.) Proc. Nat. Acad. Sci. U.S.A. 4\%, 412 (1956).

- Roy, S. N., Bernoulli's theorem and Tshebycheff's analogue, Sankhyā, 209 (1945). M

- Runnenburg (See H. Kesten). Math. Centrum Amsterdam Rep. S $\mathbf{0 3}, 16$ pp. (1956).

- Rvačeva, E. L. (See D. G. Meňzler.) Doklady Akad. Nauk SSSR 60, 1127 (1948).

- Rvačeva, E. L. (See D. G. Mě̌zler.) Ukrain. Mat. Zurnal 1, 9 (1949).

Rvačeva, E. L., On domains of attraction of multi-

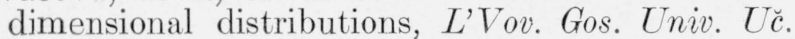

Zap. 29, Ser. Meh.-Mat. No. 6, 5 (1954).

M 1\%, 864

Rvačeva, E. L., On the maximum discrepancy between two empirical distributions, Ukrain. Mat. Zurnal 4, 373 (1952).

M 15, 635

Rvačova, K. L., Domains of attraction of many dimensional stable distributions, Dopovidi Akad. Nauk Ukrain. RSR. 1950, 179 (1950).

M 13, 663

Rvačova, K. L., A many dimensional local theorem for stable limit distributions, Dopovidi Akad. Nauk Ukrain. RSR. 1950, 183 (1950). M 13, 663

Sakaguchi, M., On a certain limit distribution, Rep. Statist. Appl. Res. Union Jap. Sci. Eng. 1, 10 (1952).

M 14, 567

Salem, R., Some properties of trigonometric series whose terms have random signs, Acta. Math. 91, 245 (1954).

M 16. 467 Sapogov, N. A. (See Y. V. Linnik) Izvestiya Akad. Nauk SSSR Ser. mat. 13, 533 (1949).

Sapogov, N. A., On sums of dependent random variables, Doklady Akad. Nauk SSSR 63, 353 (1948).

M 10, 310

Sapogov, N. A., On the law of the iterated logarithm for dependent variables, Doklady Akad. Nauk SSSR 63, 487 (1948). M 10, 381

Sapogov, N. A., The problem of stability for a theorem of Cramér's, Vestnik Leningrad. Unii. 10, 61 (1955).

M 18, 753

Sapogov, N. A., Law of the iterated logarithm for sums of dependent quantities, Leningrad. Gos. Univ. Uč. Zap. 13\%, 160 (1950).

M 1\%, 1217

Sapogov, N. A., A two-dimensional limit theorem for two-dimensional chains, Izvestiya Akad. Nauk SSSR. Ser. Mat. 13, 301 (1949). M 11, 40

Sapogov, N. A., On the strong law of large numbers, Uspehi Matem. Nauk 4, 194 (1949). M 11, 189

Sapogov, N. A., An integral limit theorem for multidimensional Markov chains, Uspehi Matem. Nauk 4, 190 (1949). M 11, 189

Sapogov, N. A., On a limit theorem, Doklady Akad. Nauk SSSR 69, 15 (1949).

M 11, 256

Sapogov, N. A., General form of a limit theorem for independent random vectors, Doklady Akad. Nauk SSSR y0, 765 (1950).

M 11, 444

Sapogov, N. A., On the law of large numbers for dependent random variables, Izvestiya Akad. Nauk SSSR Ser. Mat. 14, 145 (1950).

M 11, 606

Sapogov, N. A., On a multidimensional limit theorem of the theory of probability, Uspehi Matem. Nauk 5, 137 (1950).

M 1\%, 34

Šaragina, Z. I., Local limit theorems for certain schemes of cyclic processes, Doklady Akad. Nauk SSSR 110, 521 (1956).

M 18, 944

Sarmanov, O. V., Generalization of a limit theorem of the theory of probability to sums of almost independent variables satisfying Lindeberg's condition, Izvestiya Akad. Nauk SSSR 11, 569 (1947).

М 9, 361

Sarymsakov, T. A., The law of the iterated logarithm for Markov chains, Doklady Akad. Nauk SSSR 59, 1249 (1948).
M 9, 451 
Savkevitch, V., Sur le schéma des urnes à composition variable, C. R. Doklady Acad. Sci. URSS 28, 8 (1940).

M 2, 229

Saxer, W., Über die Entwicklung des zentralen Grenzwertsatzes der Wahrscheinlichkeitsrechnung. Elemente der Math. 5, 50 (1950).

M 11, 707

Schärf, H., Über partielle Bestandsänderungen und eine Klasse neuer Integrationsprozesse, Mitt. Verein. Schweiz. Versich.-Math. 44, 233 (1944).

M $\boldsymbol{\gamma}, 209$

Scheifé, H., A useful convergence theorem for probability distributions, Ann. Math. Statist. 18, 434 (1947)

M 9, 83

von Schelling, H. (See E. J. Gumbel), Ann. Math. Statist. 21, 247 (1950).

Schmid, P., Sur les théorèmes asymptotiques de Kolmogoroif et Smirnov pour des fonctions de distribution discontinues, C.R. Acad. Sci. Paris 243, 349 (1956).

M 18, 75

Schulz, G., Grenzwertsätze für die Wahrscheinlich-

- keiten verketteter Ereignisse, Deutsche Math. 1,

665 (1936).

Z 15, 167

Schulz, G., Das Summenproblem bei mehrdimensionalen arithmetischen Wahrscheinlichkeitsverteilungen, Ber. Math.-Tagung Tübingen 1946, 131 (1947).

M 9, 46

Schutzenberger, M. P., Sur certains paramètres caractéristiques des systèmes d'événements compatibles et dépendants et leur application au calcul des cumulants de la répétition, $C . R$. Acad. Sci. Paris 225, 277 (1947).

M 9, 96

- Seitz, J., Remark concerning a paper of Kolmogorov and Prochorov, Čehoslovack Mat. Z̆. 3, 89 (1953).

M 15, 805

Selberg, H. L., Über die Darstellung willkürlicher Funktionen durch Charliersche Differenzreihen, Skand. Aktuarietidskr. 25, 228 (1942). M \%, 292

Shapiro, J. M., Error estimates for certain probability limit theorems, Ann. Math. Statist. $\mathbf{2 6 ,} 617$ (1955).

M 1\%, 754

Silber, J., Multiple sampling for variables, Ann. Math. Statist. 19, 246 (1948).

M 10, 132

Silberstein, L., Solution of the restricted problem of the random walk, Philos. Mag. 35, 538 (1944).

M 6, 88

Silberstein, L., The accumulation of chance effects and the Gaussian frequency distribution, Philos. Mag. 35, 395 (1944).

M 6, 88

Simaika, J. B., On the significance of a typical value in the renewal theory, Skand. Aktuarietidskr. 30, 121 (1947).

M 9, 452

Siraždinov, S. H., Refinement of limiting theorems for stationary Markov chains, Doklady Akad. Nauk SSSR 84, 1143 (1952).

M 14, 187

Sirokorad, B. V., On the applicability of the central limit theorem to Markov chains, Izvestiya Akad. Nauk SSSR Ser. Mat. 18, 95 (1954). M 15, 635

Skorohod, A. V., On a class of limit theorems for Markơf chains, Dokl. Akad. Nauk SSSR 106, 781 (1956).

M 1\%, 1217

Skorohod, A. V., On the limiting transition from a sequence of sums of independent random quantities to a homogeneous random process with independent increments, Dokl. Akad. Nauk SSSR 104, 364 (1955).

M 1\%, 1096

Skorohod, A. V., Limit theorems for stochastic processes, Teor. Veroyatnost. i Primenen 1, 289 (1956).

M 18, 943

Skorohod, A. V., On a theorem relative to stable distributions, Uspehi Matem. Nauk 9, 189 (1954).

M 16, 52

Smirnoff, N., Sur un théorème limite dans un schèma d'épreuves indépendantes, Bull. Acad. Sci. URSS, Ser. Math. 1939, 319 (1939).

Z 24, 264

Smirnoff, N., Sur la distribution de $\omega^{2}$ (Critérium de M. R. v. Misès), C.R. Acad. Sci., Paris 202, 449 (1936).

Z 13, 173

Smirnov, N. V., Approximate laws of distribution of random variables from empirical data, Uspehi Matem. Nauk 10, 179 (1944).

M $\boldsymbol{\gamma}, 19$

Smirnov, N. V., On the distribution of the number of cycles in cyclic systems, Uspehi Matem. Nauk 4, $192(1949)$.

M 11, 189

Smirnov, N. V., Limit distributions for the terms of a variational series; [Amer. Math. Soc. Translation No. 6\%, (1952).] Trudy Mat. Inst. Steklov. 25, 60 pp (1949).

M 11, 605

Smith, J. C., Asymptotic distribution of sums of Rademacher functions, Bull. Amer. Math. Soc. 51, 941 (1945).

M $\boldsymbol{7}, 208$

Smith, W. L., A frequency-function form of the central limit theorem, Proc. Cambridge Philos. Soc. 49, 462 (1953).

M 14, 1099

Smith, W. L., Extensions of a renewal theorem, Proc. Cambridge Philos. Soc. 51, 629 (1955). M 1\%, 165 Smith, W. L., Asymptotic renewal theorems, Proc. Roy. Soc. Edinburgh Sect. A 64, 9 (1954). M 15, 722 -Smith, W. L., (See D. R. Cox) Skand. Aktuarietidskr 36, 139 (1953).

Spaček, A., Note on successive cumulative sums of independent random variables, Časopis Pést. Mat. Fys. $\mathbf{7 4 ,} 41$ (1949).

M 11, 256

Sparre Andersen, E., On the fluctuations of sums of random variables. II. Math. Scand. 2, 195 (1954).

M 16, 839

Spitzer, F., A combinatorial lemma and its application to probability theory, Trans. Amer. Math. Soc. 82, 323 (1956).

M 18, 156

Steinhaus, H., Sur les fonctions indépendantes. VIII. Studia Math. 11, 133 (1949). M 14, 994

Steinhaus, H., (See M. Kac) Studia Math. 6, 89 (1936).

Steinhaus, H., (See M. Kac) Studia Math. 6, 59 (1936).

Sternberg, W., The general limit theorem in the theory of probability, Bull. Amer. Math. Soc. 46, 292 (1940).

M 1, 246

Sugiyama, H., On the asymptotic behavior of $\Sigma p_{m}^{2}$ in case of certain probability distributions. I. Math. Japonicae 2, 187 (1952).

M 14, 993

- Sultanova, M., (See T. A. Sarymsakov) Doklady Akad. Nauk SSSR 59, 1249 (1948).

Sverdrup, E., The limit distribution of a continuous function of random variables, Skand. Aktuarietidskr 35, 1 (1952). 
Täcklind, Sur le risque de ruine dans des jeux inéquitables, Skand. Aktuarietidskr. 25, 1 (1942).

M $\boldsymbol{\gamma}, 209$

Takács, L., On processes of "happenings" generated by a Poisson process, Magyar Tud. Akad. Mat. Fiz. Oszt. Közl. 4, 525 (1954).

M 16, 723

Takács, L., On secondary processes derived from a Poisson process and their physical applications. With an appendix by Alfréd Rényi, Magyar Tud. Akad. Mat. Fiz. Oszt. Közl. 4, 473 (1954).

M 16, 723

Takács, L., Discussion of phenomena of occurrence and coincidence in case the distribution of the duration of happenings is arbitrary, Magyar Tud. Akad. Mat. Fiz. Oszt. Közl. 1, 371 (1951).

M 13, 956

Takács, L., Occurrence and coincidence phenomena in case of happenings with arbitrary distribution law of duration, Acta Math. Acad. Sci. Hungar. 2, 275 (1951).

M 14, 388

Takács, L., Wahrscheinlichkeitstheoretische Behandlung von Koinzidenz-Erscheinungen, mit Ereignissen gleicher Zeitdauer, $C$. R. Premier Cong. Math.pp.731-740, (Akad. Kiado, Budapest, 1952).

M 14, 1101

Takahashi, S., On the series of some independent random variables, Sci. Rep. Kanazawa Univ. 3, 209 (1955).

M 18, 75

Takahashi, S., On the central limit theorem, Tôhoku Math. J. 3, 316 (1951).

M 13, 853

Takahashi, S., On the convergence of some random Riemann-sums, Sci. Rep. Kanazawa Univ. 4, 29 (1955).

M 1\%, 1096

Takahashi, S., On the asymptotic distribution of the sum of independent random variables, Proc. Japan Acad. 2\%, 393 (1951)

M 13, 959

- Takahashi, S., (See N. Matsuyama) Sci. Rep. Kanazawa Univ. 4, 177 (1956).

Takano, K., On some limit theorems of probability distributions, Ann. Inst. Statist. Math. Tokyo 6, 37 (1954).

M 16, 149

Takano, K., Central convergence criterion in the multidimensional case, Ann. Inst. Statist. Math. Tokyo \%, 95 (1956).

M 18, 156

Takano, K., Multidimensional central limit criterion in the case of bounded variances, Ann. Inst. Statist. Math. Tokyo y, 81 (1956).

M 18, 156

Takano, K., On the convergence of classes of distributions, Ann. Inst. Statist. Math, Tokyo 3, 7 (1951).

М 13, 566

Thomasian, A. J., Distances et normes sur les espaces de variables aléatoires, C.R. Acad. Sci. Paris $\mathbf{2 4 \% ,}$ 447 (1956).

M 1\%, 864

Törnqvist, L., On the distribution function for a function of $n$ statistic variables and the central limit theorem in the mathematical theory of probability, Skand. Aktuarietidskr 29, 206 (1946).

M 8, 389

Tsuchikura, T., On the function $t-[t]-1 / 2$, Tôhoku Math. J. 3, 208 (1951).

M 13, 566

Tsurumi, S., On the strong law of large numbers, Tôhoku Math. J. \%, 166 (1955).
Tumanyan, S. H., On the asymptotic distribution of the $\chi^{2}$ criterion, Doklady Akad. Nauk SSSR 94, 1011 (1954).

M 15, 806

Udagawa, M., On numbers of positive sums of independent random variables, Kōdai Math. Sem. Rep. 1952, 45 (1952).

M 14, 294

Udagawa, M., Asymptotic properties of distributions of some functionals of random variables, Rep. Statist. Appl. Res. Union Jap. Sci. Eng. 2, 1 (1952).

M 15, 139

Udagawa, M., (See T. Kawata) Kōdai Math. Sem. Rep. 1951, 78 (1951).

Ugaheri, T., On a limit distribution, Ann. Inst. Statist. Math, Tokyo 1, 157 (1950).

M 11, 731

Ugaheri, T., On a certain sequence of chance variables, Kōdai Math. Sem. Rep. 3, 25 (1949).

M 11, 118

Urbanik, K., (See M. Fisz) Studia Math. 15, 328 (1956).

Urbanik, K., (See A. Prékopa) Acta Math, Acad. Sci. Hungar. \%, 11 (1956).

Uspensky, J. V., On the problem of the ruin of gamblers, Publ. Inst. Mat. Univ. Nac. Litoral y, 155 (1945).

M $\boldsymbol{g}, 18$

-Van Veen, S. C., (See O. Bottema) Nieuw Arch. Wiskde. 2\%, 15 (1943).

- Van Veen, S. C. (See O. Bottema) Nieuw Arch. Wiskunde 2\%, 123 (1946).

Vorob'ev, N. N., Addition of independent random variables on finite abelian groups, Mat. Sbornik 34, 89 (1954).

M 15, 882

Wald, A., On cumulative sums of random variables, Ann. Math. Statist. 15, 283 (1944). M 6, 88

Wald, A., Some generalizations of the theory of cumulative sums of random variables, Ann. Math. Statist. 16, 287 (1945).

M $\boldsymbol{\%}, 209$

Wald, A., Limit distribution of the maximum and minimum of successive cumulative sums of random variables, Bull. Amer. Math. Soc. 53, 142 (1947).

M 8, 471

Wald, A., On the distribution of the maximum of successive cumulative sums of independently but not identically distributed chance variables, Bull. Amer. Math. Soc. 54, 422 (1948). $\quad$ M 9, 519

Wald, A., (See H. B. Mann) Ann. Math. Statist. 14, 217 (1943).

-Wald, A., (See H. B. Mann) Econometrica 11, 173 (1943).

Wang, S. J., On the limiting distribution of the ratio of two empirical distributions, Acta Math. Sinica 5, 253 (1955).

M 1\%, 275

Wang, S. J., Proof of a probability theorem related to complete convergence by the method of the characteristic function, Acad. Sinica Science Record 4, 201 (1951).

M 15, 969

Weiss, L., The stochastic convergence of a function of sample successive differences, Ann. Math. Statist. 26, 532 (1955).

M 1\%, 48

Weiss, L., A certain class of solutions to a moment problem, Ann. Math. Statist. 2\%, 851 (1956).

M 18, 158 
Wiener, N., Harmonic analysis and ergodic theory, Amer. J. Math. 63, 415 (1941).

M 2,319

- Winkelbauer, K. (See J. Seitz). Cehoslovak. Mat. Z. 3, 89 (I953).

Wintner, A., (See P. Hartman) Amer. J. Math.62, $759(1940)$.

- Wintner, A., (See P. Hartman) Amer. J. Math. 63, 169 (1941).

- Wintner, A., (See N. Wiener) Amer.'J. Math. 63, 415 (1941).

- Wintner, A., On the iteration of distribution functions in the calculus of probability, Union Mat. Argentina, Publ. No. 18, 12 pp. (1941). M 3, 2

Wintner, A., (See E. R. van Kampen) Amer. J. Math. 61, 965 (1939).

Wolfowitz, J., Note on runs of consecutive elements, Ann. Math. Statist. 15, 97 (1944).

M 6, 5

Wolfowitz, J., Asymptotic distribution of runs up and down, Ann Math. Statist. 15, 163 (1944).

M 6, 8

Wolfowitz, J., Estimation by the minimum distance method in nonparametric stochastic difference equations, Ann. Math. Statist. 25, 203 (1954).
Wolfowitz, J., (See A. Dvoretzky) Duke Math. J. 18, 501 (1951).

Wolfowitz, J., (See K. L. Chung) Ann. of Math. 55, 1 (1952).

- Woodbury, M. A., (See C. L. Dolph) Trans Amer. Math Soc. $\mathbf{2}, 519$ (1952)

Yntema, L., An elementary proof of the central limit theorem, Verzekerings-Arch. Actuarieel Bijvoegsel 33, 19 (1956).

M 18, 76

Yuškeviê, A. A., On limit theorems connected with the concept of entropy of Markov chains, Uspehi Matem. Nauk 8, 177 (1953).

M 15, 635

Zuckerman, H. S., (See Z. W. Birnbaum) Amer. J. Math. 62, 787 (1940).

-Zuckerman, H. S., (See E. Hewitt) Duke Math. J. 22, 595 (1955)

-Zygmund, A., (See R. Salem) Acta Math. 91, 245 (1954).

- Zygmund, A., (See J. Marcinkiewicz) Fundam. Math. 29, 215 (1937). 


\author{
(Including papers in outside journals)
}

\author{
Selected Abstracts
}

Propagation at oblique incidence over cylindrical obstacles, M. P. Bachynski, J. Research NBS 64D, No. 4, 311 (1960). Investigations of propagation of short electromagnetic waves at oblique incidence over smooth, perfectly conducting cylindrical obstacles are described. It is shown that the effect of oblique incidence can be considered as a change in the effective radius of curvature of the diffracting obstacle. The power in the shadow region of a cylindrical obstacle decreases with angle of obliqueness for horizontally polarized waves and can decrease, remain constant, or increase with angle of obliqueness for vertically polarized waves depending on the geometry of the propagation link. In all cases, vertical polarization gives a stronger field in the shadow region than horizontal polarization. In addition it is shown that the diffracted field behind an obstruction of uniform radius of curvature is the same as that behind an obstacle of uniformly varying radius of curvature, provided the effective radius is the same.

Diffraction by smooth conical obstacles, H. E. J. Neugebauer and M. P. Bachynski, J. Research NBS 64D, No. 4, 317 (1960). Expressions, obtained earlier for the calculation of diffraction due to conducting obstacles with smooth cylindrical surfaces, are generalized to oblique incidence and to surfaces of conical shape. The derivation is based on a generalized concept of the Green's function and on the use of corrective factors that take the same place as corrections introduced by other authors into the theory of diffraction by apertures. The final expressions for conical obstacles and oblique incidence are very similar to those for cylindrical obstacles. The results are compared with scale model measurements.

Mode theory and the propagation of ELF radio waves, J. R. Wait, J. Research NBS 64D, No. 4, 387 (1960).

The mode theory of propagation of electromagnetic waves at extremely-low-frequencies $(1.0$ to $3000 \mathrm{c} / \mathrm{s})$ is treated in this paper. Starting with the representation of the field as a sum of modes, approximate formulas are presented for the attenuation and phase constants. Certain alternate representations of the individual modes are mentioned. These are used as a basis for describing the physical behavior of the field at large distances from the source, particularly near the antipode of the source. At the shorter distances, where the range is comparable to the wavelength, the spherical-earth mode series is best transformed to a series involving cylindrical wave functions. This latter form is used to evaluate the near field behavior of the various field components.

The effect of the earth's magnetic field is also evaluated using a quasi-longitudinal approximation. In general it is indicated that if the gyrofrequency is less than the effective value of the collision frequency, the presence of the earth's magnetic field may be neglected for ELF. When this condition is not met the attenuation may be increased somewhat. The influence of an inhomogeneous ionosphere is also briefly considered and, finally, the propagation of ELF pulses are treated. It is suggested that certain observed characteristics of ELF waveforms may be attributed to the inclination of the current channel in the lightning discharge.

On the diffraction of electromagnetic pulses by curved conducting surfaces, J. R. Wait and A. M. Conda, Can. J. Phys. 37,1384 (1959).

Starting with the known steady-state solutions for diffraction by a perfectly conducting convex surface, the corresponding transient responses are derived using Fourier-Laplace inversion. Explicit results are given for an incident wave which varies with time as a step function.
Leonard Euler's integral: A historical profile of the gamma function, P. J. Davis, Am. Math. Mo. 66, 849 (1959).

This survey article shows how the gamma function grew in concept and in content from the time of Euler to the recent treatise of Bourbaki and how in this growth it partook of the general development of mathematics over the past two and a quarter centuries.

Confidence intervals for the expectation of a Poisson variable, E. L. Crow and R. S. Gardner, Biometrika 46, 441 (1959). A table of "optimum" two-sided confidence intervals for the mean of a Poisson variable is presented for confidence coefficients 80, 90, 95, 99, and 99.9 percent and all values of the variable from 0 through 300 . The intervals are compared in length with other existing or possible systems of intervals for the Poisson mean. The method of calculation is stated, and an interesting property of Poisson probability sums useful in the calculation is derived.

Use of the equation of hydrostatic equilibrium in determining the temperature distribution in the outer solar atmosphere, S. R. Pottasch, Astrophys. J. 131, No. 1, 68 (1960).

The temperature distribution from $1.0043(3000 \mathrm{~km})$ to 20 solar radii in the sun's atmosphere is computed from the observed density distribution in this region and the assumption of hydrostatic equilibrium. The temperature distribution shows a maximum between 1.1 and 3 solar radii and a decrease in temperature thereafter. This decrease in temperature is consistent with Chapman's suggestion of thermal conduction only if loss of energy by radiation is included. Inclusion of a radiative energy loss also is shown to invalidate Parker's argument against hydrostatic equilibrium out to large distances from the sun.

On the convergence of the Rayleigh quotient iteration for the computation of characteristic roots and vectors, VI. (Usual Rayleigh quotient for nonlinear elementary divisors), A. M. Ostrowski, Arch. Rat. Mech. Anal. 4, No. 2, 153 (1959).

In this paper the classical Rayleigh quotient iteration is discussed for eigenvalues with non-linear elementary divisors. The convergence of the method is only then satisfactory, if it is combined with the accelerating methods of Steffensen and Householder, but in this last case it turns out to be at least as good as the method of the generalized Rayleigh quotient.

Tables for the statistical prediction of radio ray bending and elevation angle error using surface values of the refractive index, B. R. Bean, B. A. Cahoon, and G. D. Thayer, NBS Tech. Note 44 (PB151403) (1960) 50 cents.

Radio ray bending, $\tau$, and elevation angle error, $\epsilon$, have been calculated for a wide range of meteorological conditions at 13 climatically diverse U.S. radiosonde stations. The parameters in the observed linear regression equations of $\tau$ and $\epsilon$ upon the surface value of the refractive index are given for heights of 0.1 to 70 kilometers and initial elevation angles of the ray from 0 to 900 milliradians.

Weighted restricted partitions, M. Newman, Acta Arith. V, 371 (1959).

Let $q_{1}(n)$ be the number of partitions of $n$ into parts not divisible by $q$, and define $q_{s}(n)$ by $\left\{\Sigma q_{1}(n) x^{n}\right\}^{s}=\Sigma q_{s}(n) x^{n}$. In this article recurrence formulas for these coefficients of lengths independent of $n$ are derived when $q$ is any of the primes, 2, 3, 5, 7, 13 . 
A continuous poker game, A. J. Goldman and J. J. Stone, Duke Math. J. 27, No. 1, 41 (1960).

In this paper we derive the solutions of a zero-sum two-person poker game in which the players' hands are independent random numbers from the intervals $[0,1]$. The game involves two bet levels $a, b$ and an ante of 1 unit $(a>b>1)$. The players act alternately, and one of them is permitted a single raise.

Our model subsumes the alternating-bid von Neumann poker game of [4] as well as the model solved by Bellman [1]. The former arises from the limiting case $b=1$, the latter as the "equal increments" case $a-b=b-1$. (Karlin and Restrepo [3] have recently solved the equal increments game with $n$ rounds of bidding.) The solution exhibits qualitative features like those of [4] and [1] and turns out to depend on a decomposition of $[0,1]$ into three subintervals corresponding to low hands, intermediate hands and high hands. Optimal strategies for the players are distinguished among the semioptimal strategies (those which achieve the value of the game against every optimal strategy of the opponent) by a specification of the average frequency of bluffing over the range of low hands and (for one player) by an integral sublinearity condition on the frequency of seeing a raise when holding an intermediate hand.

\section{List of Titles}

Journal of Research, Section 64A, No. 4, July-August 1960. 70 cents.

Gamma irradiation of hexafluorobenzene. R. E. Florin, L. A. Wall, and D. W. Brown.

Behavior of isolated disturbances superimposed on laminar flow in a rectangular pipe. Grover C. Sherlin.

Standard of spectral radiance for the region of 0.25 to 2.6 microns. Ralph Stair, Russell G. Johnston, and E. W. Halbach.

Photovoltaic effect produced in silicon solar cells by $\mathrm{X}$ - and gamma rays. Karl Scharf.

Phase equilibria in systems involving the rare-earth oxides. Part I. Polymorphism of the oxides of the trivalent rareearth ions. R. S. Roth and S. J. Schneider.

Phase equilibria in systems involving the rare-earth oxides. Part II. Solid state reactions in trivalent rare-earth oxide systems. S. J. Schneider and R. S. Roth.

Some observations on the calcium aluminate carbonate hydrates. Elmer T. Carlson and Horace A. Berman.

Acid dissociation constant and related thermodynamic quantities for triethanolammonium ion in water from $0^{\circ}$ to $50^{\circ}$ C. Roger G. Bates and Guy F. Allen.

Ionization constants of four dinitrophenols in water at $25^{\circ} \mathrm{C}$. Robert A. Robinson, Marion Maclean Davis, Maya Paabo, and Vincent E. Bower.

Dissociation constant of anisic ( $p$-methoxybenzoic) acid in the system ethanol-water at $25^{\circ} \mathrm{C}$. Elizabeth E. Sager and Vincent E. Bower.

Preparation of sulfur of high purity. Thomas J. Murphy, W. Stanley Clabaugh, and Raleigh Gilchrist.

Tritium-labeled compounds IV. D-Glucose- $6-t$, D-xylose-5- $t$, and D-mannitol-1-t. Horace S. Isbell, Harriet L. Frush, and Joseph D. Moyer.

Tritium-labeled compounds V. Radioassay of both carbon14 and tritium in films, with a proportional counter. Horace S. Isbell, Harriet L. Frush, and Nancy B. Holt.

\section{Journal of Research, Section 64C, No. 3, July-September} 1960. 75 cents.

A new method of measuring gage blocks. James B. Saunders. Gage blocks of superior stability: initial developments in materials and measurement. M. R. Meyerson, T. R. Young, and W. R. Ney.

Variation of resolving power and type of test pattern. Francis E. Washer and William P. Tayman.

A multiple isolated-input network with common output. C. M. Allred and C. C. Cook.

Phase angle master standard for 400 cycles per second. J. H. Park and H. N. Cones.
Disturbances due to the motion of a cylinder in a two-layer liquid system. Lloyd H. Carpenter and Garbis H. Keulegan.

Journal of Research, Section 64D, No. 4, July-August 1960. 70 cents.

Relation of turbulence theory to ionospheric scatter propagation experiments. Albert D. Wheelon.

Propagation at oblique incidence over cylindrical obstacles, M. P. Bachynski. (See above abstracts.)

Diffraction by smooth conical obstacles. H. E. J. Neugebauer and M. P. Bachynski. (See above abstracts.)

Characteristics of 488 megacycles per second radio signal reflected from the moon. B. C. Blevis and J. H. Chapman.

The use of polarization fading of satellite signals to study the electron content and irregularities in the ionosphere. C. Gordon Little and Robert S. Lawrence.

Note on a test of the equivalence theorem for sporadic $E$ propagation. J. W. Wright and T. N. Gautier.

Daytime attenuation rates in the very low frequency band using atmospherics. W. L. Taylor.

Measured electrical properties of snow and glacial ice. A. D. Watt and E. L. Maxwell.

Half-wave cylindrical antenna in a dissipative medium: current and impedance. Ronold W. P. King and Charles W. Harrison.

Preface to ELF papers.

Some ELF phenomena. E. T. Pierce.

Mode theory and the propagation of ELF radio waves. James R. Wait. (See above abstracts.)

Studies of natural electric and magnetic fields. G. D. Garland and T. F. Webster.

Natural electromagnetic energy below the ELF range. Wallace H. Campbell.

Possible application of the system loss concept at ELF. Kenneth A. Norton.

Measurements of the spectrum of radio noise from 50 to 100 cycles per second. M. Balser and C. A. Wagner.

Listing of published VLF symposium papers.

Use of crystal to display high energy X-ray images, J. S Pruitt, Non-Destructive Testing XVII, No. 6, 359 (1959).

The measuring process, J. Mandel, Technometries 1, No. 3, 251 (1959).

The following are published in Proc. Intern. Rubber Conf., Nov. 8 to 13,1959 (Washington, D.C., 1959):

Power loss and operating temperature of tires, R. D. Stiehler, M. N. Steel, G. G. Richey, J. Mandel, and R. H. Hobbs, p. 73

An indoor tester for measuring tire tread wear, G. G. Richey, J. Mandel, and R. D. Stiehler, p. 104.

Measurement of the aging of rubber vulcanizates, J. Mandel, F. L. Roth, M. N. Steel, and R. D. Stiehler, p. 221 .

Standard materials for rubber compounding, F. L. Roth and R. D. Stiehler, p. 232.

Thermodynamic properties of helium at low temperatures and high pressures, D. B. Mann and R. B. Stewart, J. Heat Transfer 81, 323 (1959).

Fire research at the National Bureau of Standards, A. F Robertson, Fire Research Abstr. Rev. I, No. 4, 159 (1959).

Refractive indices and transmittances of several optical glasses in the infrared, G. W. Cleek, J. J. Villa, and C. H. Hahner, J. Opt. Soc. Am. 49, No. 11, 1090 (1959).

Absolute photometry of the aurora-II. Molecular nitrogen emission in the sunlit atmosphere, M. H. Rees, J. Atmospheric and Terrest. Phys. 14, 338 (1959).

Preliminary assessment of the IGY, A. H. Shapley, Proc. Natl. Electron. Conf., p. 1 (1958).

Factorial experiments in life testing, M. Zelen, Technometrics 1, No. 3, 269 (1959).

Wave length definition of the meter, I. C. Gardner, Systems of Units, National and International Aspects, Am. Assoc. Advance. Sci., Pub. 57, p. 53 (1959).

Ethane carbon-carbon distance obtained from infrared spectra, H. C. Allen and E. K. Plyler, J. Chem. Phys. 31, No. 4, 1062 (1959). 
The anomalous inversion in cristobalite, R. F. Walker, The kinetics of high temperature processes, 228 pages (J. Wiley \& Sons, New York, N.Y., 1959).

Digital recording of electrocardiographic data for analysis by a digital computer, L. Taback, E. Marden, H. L. Mason, and H. V. Pipberger, IRE Trans. Med. Electron. ME-6, 167 (1959).

Determination of starch in paper. A comparison of the TAPPI enzymatic, and spectrophotometric methods, J. L. Harvey, B. W. Forshee, and D. G. Fletcher, Tappi 42, No. 11, 878 (1959)

Young's modulus of various refractory materials as a function of temperature, J. B. Wachtman, Jr., and D. G. Lam, Jr., J. Am. Ceram. Soc. 42, No. 5, 254 (1959).

Branched-chain higher sugars. III. A 4-C-(hydroxymethyi)pentose, R. Schaffer, J. Am. Chem. Soc. 81, 5452 (1959).

Vibrational spectrum of cyanate ion in various alkali halide lattices, A. Maki and J. C. Decius, J. Chem. Phys. 31, No. 3, 772 (1959).

Glass research at the National Bureau of Standards, C. H. Hahner, Glass Ind., p. 588 (1959).

Applications of the molecular refractivity in radio metrology, B. R. Bean and R. M. Gallet, J. Geophys. Research 64, No. 10, 1439 (1959).

Liquid helium cryostat with an integral super-conducting resonator, E. Maxwell and F. A. Schmidt, Suppl. Bull. Inst. Intern. Froid, Comm. 1, Delft, Holland, Annexe 1958-1, p. 95 (1958).

Sporadic $E$ observed on VHF oblique incidence circuits, E. K. Smith, In N. Atl. Treaty Organ., Sporadic E ionization; Ionospheric Research Meeting, AGARD Avionics Panel, Cambridge, England, Sept. 1958 (AGARDograph 34), p. 129 (1958).

Low-temperature transport properties of copper and its dilute alloys: Pure copper, annealed and cold-drawn, R. L. Powell, H. M. Roder, and W. J. Hall, Phys. Rev. 115, 314 (1959).

The double bond isomerization of olefins by hydrogen atoms at $-195^{\circ}$, M. D. Scheer and R. Klein, J. Phys. Chem. 63, 1517 (1959).

Paramagnetic resonance in the free hydroxyl radical, H. E. Radford, Nuovo Cimento [X] 14, 245 (1959).

Optical measurements on thin films of condensed gases at low temperatures, J. Kruger and W. J. Ambs, J. Opt. Soc. Am. 44, 1195 (1959).

On the convergence of Gauss' alternating procedure in the method of least squares, A. M. Ostrowski, Ann. Mat. Pura Appl. (Bologna, Italy) (IV) 48, 229 (1959).

The earth and its environment, S. Chapman, Proc. IRE 47, No. 2, 137 (1959).

Bremsstrahlung cross-section formulas and related data, H. W. Koch and J. W. Motz, Rev. Mod. Phys. 31, No. 4, 920 (1959).

Note on quiet-day vertical cross sections of the ionosphere along $75^{\circ} \mathrm{W}$ geographic meridian, J. W. Wright, Letter J. Geophys. Research 64, 1631 (1959).

Effect of atomic tests on radio noise, C. A. Samson, Letter Nature 184, 538 (1959).

Short-time stability of a quartz-crystal oscillator as measured with an ammonia maser, A. H. Morgan and J. A. Barnes, Letter Proc. IRE 47, 1782 (1959).

Interplanetary gas. I. Hydrogen radiation in the night sky, J. C. Brandt and J. W. Chamberlain, Astrophys. J. 130, $670(1959)$.

The nova outburst. III. The ionization of hydrogen gas by an exciting star, J. Jefferies and S. Pottasch, Ann. Astrophys. J. 22, 318 (1959).

Exploratory study, by low temperature X-ray diffraction techniques, of diborane and the products of a microwave discharge in diborane, L. H. Bolz, F. A. Mauer, and H. S. Peiser, J. Chem. Phys. 31, No. 4, 1005 (1959).

Some clinical applications of research findings in dental materials, G. C. Paffenbarger, Ohio Dental J. 33, No. 3, 218 (1959).

Spectral study of a visible, short-duration afterglow in nitrogen, B. E. Beale, Jr., and H. P. Broida, J. Chem. Phys. 31, No. 4, 1030 (1959).
Atomic electron affinities, F. Rohrlich, Nature 183, 244 (1959).

Cavity resonators for dielectric spectroscopy of compressed gases, H. E. Bussey and G. Birnbaum, Rev. Sci. Instr. 30, 800 (1959).

A discussion of federal specifications GS-X-620 and $\mathrm{L}-\mathrm{F}-310$ for dental X-ray apparatus and dental X-ray film, G. C. Paffenbarger, A. F. Forziati, and M. P. Kumpula, J. Am. Dental Assoc. 59, 472 (1959)

Dynamic stability of frozen radicals. II. The formal theory of the model, J. L. Jackson, J. Chem. Phys. 31, No. 3, 722 (1959).

An additional lunar influence on equatorial $E_{s}$ at Huancayo, R. W. Knecht, Research Note J. Atmospheric and Terrest. Phys. 14, 348 (1959).

Method of cooling head-on photomultipliers, G. C. Harman, Rev. Sci. Instr. 30, No. 8, 742 (1959).

On artificial geomagnetic and ionospheric storms associated with high-altitude explosions, S. Matsushita, J. Geophys. Research 6, 1149 (1959).

An intermittent-action camera with absolute time calibration, R. G. Hefley, R. H. Doherty, and E. L. Berger, IRE Wescon Conv. Record 3, Pt. 6, 129 (1959).

Nonresonant microwave absorption and electric dipole moment of $\mathrm{NO}$ in the gaseous state, A. A. Maryott and S. J. Kryder, J. Chem. Phys. 31, No. 3, 617 (1959).

Transistor $\mathrm{P}-\mathrm{A}$ amplifier, G. F. Montgomery and F. R. Bretemps, Electronic Ind. 19, No. 1, 196 (1960).

Sorting devices in postal tests. 1: Proposal for an electromagnetic sorter, S. Henig, Automatic Control 11, No. 6, 6 (1959).

The dissociation constant of $\mathrm{CaOH}^{+}$from $0^{\circ}$ to $40^{\circ} \mathrm{C}$, R. G. Bates, V. E. Bower, R. G. Canham, and J. E. Prue, Trans. Faraday Soc. 55, No. 444, 2062 (1959).

Evaluation of chemical analyses on two rocks, W. J. Youden, Technometrics 1, No. 4, 409 (1959).

Nuclear electronics, L. Costrell, Nucleonics Mag. 18, No. 1, 124 (1960)

Microscopical studies of failure in polymers, S. B. Newman, ASTM Spec. Tech. Pub. 257, 132 (1959).

Flare-associated bursts at $18 \mathrm{Mc} / \mathrm{s}, \mathrm{C}$. Warwick and J. W Warwick, Paris Symp. on Radio Astron. p. 203 (IAU Symp. No. 9 and URSI Symp. No. 1, 1959).

Electromagnetic radiation from cylindrical structures, J. R. Wait (Pergammon Press, Inc., New York, N.Y., 1959).

Standard X-ray diffraction powder patterns, H. E. Swanson, M. I. Cook, T. Isaacs, and E. H. Evans, NBS Circ. 539, Vol. 9 (1960) 40 cents.

Properties of high-temperature ceramics and cermetsElasticity and density at room temperature, S. M. Lang, NBS Monograph 6 (1960) 20 cents.

Precise measurement of heat of combustion with a bomb calorimeter, R. S. Jessup, NBS Monograph 7 (1960) 25 cents.

Conductive flooring for hospital operating rooms, T. H. Boone, F. L. Hermach, E. H. MacArthur, and R. C. McAuliff, NBS Monograph 11 (1960) 20 cents.

Tabulation of data on receiving tubes, C. P. Marsden, W. J. Keery, and J. K. Moffitt, NBS Handb. 68 (1959) \$1.00.

Survey of Central Radio Propagation Laboratory research in tropospheric propagation 1948-1956, J. W. Herbstreit and P. L. Rice, NBS Tech. Note 26 (PB151385) (1959) \$4.00.

Distribution of incoming lettermail at the Baltimore, Maryland City Post Office, B. M. Levin and A. E. Newman, NBS Tech. Note 33 (PB151392) (1959) \$2.50.

A multiplet table of astrophysical interest, C. E. Moore, NBS Tech. Note 36 (PB151395) (1959) \$4.00.

Application of RF micropotentiometers for calibration of signal generators to $1000 \mathrm{Mc}, \mathrm{L}$. F. Behrent, NBS Tech. Note 37 (PB151396) (1960) 50 cents.

Design and construction of a liquid hydrogen temperature refrigeration system, D. B. Chelton, J. W. Dean, and B. W. Birmingham, NBS Tech. Note 38 (PB151397) (1960) 75 cents.

Helium refrigeration and liquefaction using a liquid hydrogen refrigerator for precooling, D. B. Chelton, J. W. Dean, and T. R. Strobridge, NBS Tech. Note 39 (PB151398) (1960) 50 cents. 
Mean electron density variations of the quiet ionosphere I-March 1959, J. W. Wright and L. A. Fine, NBS Tech. Note 40-1 (PB151399-1) (1960) \$1.25.

Mean electron density variations of the quiet ionosphere 2 April 1959, J. W. Wright and L. A. Fine, NBS Tech. Note 40-2 (PB151399-2) (1960) \$1.25.

Expendable modules as bases for disposal-at-failure maintenance, R. O. Stone, P. Meissner, and K. M. Schwarz, NBS Tech. Note 41 (PB151400) (1960) $\$ 2.25$.

Analog-digital conversion equipment for electrocardiographic data, L. Taback, NBS Tech. Note 42 (PB151401) (1960) $\$ 1.25$.

A summary of VHF and UHF tropospheric transmission loss data and their long-term variability, D. A. Williamson, V. L. Fuller, A. G. Longley, and P. L. Rice, NBS Tech. Note 43 (PB151402) (1960) \$2.25.

Operating instructions for $\mathrm{ARN}-2$ auxiliary log-linear noise recorder, R. T. Disney and C. A. Samson, NBS Tech. Note 45 (PB151404) (1960) 50 cents.

Quantum-mechanical calculation of the probability of an exchange reaction for constrained linear encounters, J. Mazur and R. J. Rubin, J. Chem. Phys. 31, No. 5, 1395 (1959).

Monte Carlo calculations of gamma ray backscattering, M. J. Berger and D. J. Raso, Radiation Research 12, No. 1, 20 (1960).

Identification of textile coatings by infrared spectroscopy, F. H. Forziati, R. T. Hite, and M. K. Wharton, Am. Dyestuff Reptr. 49, No. 4, 29 (1960).

New wavelengths for some helium (He I) lines, W. C. Martin, J. Opt. Soc. Am. 50, No. 2, 174 (1960).

Geomagnetic effects of high-altitude nuclear explosions, A. G. MeNish, J. Geophys. Research 64, No. 12, 2253 (1959).

Propagation and production of electromagnetic waves in a plasma, R. Gallet, Nuovo Cimento Suppl. 13, No. 1, 234 (1959).

Fading rate recorder for propagation research, J. W. Koch, W. B. Harding, and R. J. Jansen, Electronies 32, No. 51, 78 (1959)

Matrix algebra for calculating multicomponent mixtures, F. Ordway, Portland Cement Assoc. J. Research and Devel. Labs. 2, No. 1, 28 (1960).

Determination of piezoelectric properties as a function of pressure and temperature, J. E. McKinney and C. S. Bowyer, J. Acoust. Soc. Am. 32, No. 1, 56 (1960).

Line shape and $f$ value in the $\mathrm{OH}^{2} \Sigma^{+}-{ }^{2} \pi$ transition, T. Carrington, J. Chem. Phys. 31, No. 5, 1243 (1959).

Determination of the recording performance of a tape from its magnetic properties, E. D. Daniel and I. Levine, J. Acoust. Soc. Am. 32, No. 2, 258 (1960)

Gages for measuring the thickness of chromium on the internal surface of small-bore tubes, V. A. Lamb and P. A. Krasley, Plating 47, No. 2, 176 (1960).

Departures from the Saha equation under varying conditions of Lyman continuous opacity, S. R. Pottasch and R. N. Thomas, Astrophys. J. 130, No. 3, 941 (1959).

Experimental and theoretical investigation of the magnetic properties of iron oxide recording tape, E. D. Daniel and I. Levine, J. Acoust. Soc. Am. 32, No. 1, 1 (1960).

Vibration-rotation bands of ammonia. IV. The stretching fundamentals and associated bands near $3 \mu$, W. S. Benedict, E. K. Plyler, and E. D. Tidwell, J. Chem. Phys. 32, No. 1, $32(1960)$

Electron impact studies of aromatic hydrocarbons. I. Benzene, napthalene, anthracene, and phenanthrene, M. E. Wacks and V. H. Dibeler, J. Chem. Phys. 31, No. 6 , 1557 (1959)

Value of the Rydberg constant, W. C. Martin, Phys. Rev. 116, No. 3, 65் (1959).

Characteristics of deposits, W. H. Metzger, Jr., Symp. Electroless Nickel Plating, ASTM Spec. Tech. Pub. 265, p. $13(1959)$.

Turbulent motion, G. B. Schubauer and C. M. Tchen, sec. B, vol. 5, Princeton Ser., High speed aerodynamics and jet propulsion, turbulent flows and heat transfer, p. 75 (Princeton Univ. Press, Princeton, N.J., 1959)
Electron characteristic energy losses in some intermetallic compounds, B. Gauthe, Phys. Rev. 114, No. 5, 1265 (1959). Adsorption, diffusion, and evaporation of carbon monoxide or tungsten, R. Klein, J. Chem. Phys. 31, No. 5, 1306 (1959).

Efficient harmonic generation, G. F. Montgomery, Proc IRE 48, No. 2, 251 (1960).

The ninth plenary assembly of the CCIR, J. W. Herbstreit, IRE Proc. 48, 45 (1960).

Effect of fluorides on infrared transmittance of certain silicate glasses, G. W. Cleek and T. S. Scuderi, J. Am. Ceram Soc. 42, No. 12, 599 (1959)

Studies of borate minerals. VI: Veatchite, J. R. Clark, M. E. Morse, A. Perloff, and G. Burley, Am. Mineralogist 44, No. 11-12, 1141 (1959)

Conditions at the ionization and shock fronts in collisions of gas clouds-Bright rims in diffuse nebulae, pt. VI, S. R. Pottasch, Rev. Mod. Phys. 30, No. 3, 1053 (1958).

The adhesion of electrodeposited nickel to chromium a elevated temperatures, W. E. Reid, Jr., and F. Ogburn, J. Electrochem. Soc. 10\%, No. 2, 91 (1960)

Chloride content of the diffusion layer at a silver anode, P. A. Krasley, J. Electrochem. Soc. 107, No. 2, 139 (1960)

Spectral emittance of ceramic-coated and uncoated specimens of Inconel and stainless steel, J. C. Richmond and J. E. Stewart, J. Am. Ceram. Soc. 42, No. 12, 633 (1959).

Mismatch errors in cascade-connected variable attenuators G. E. Schafer and A. Y. Rumfelt, IRE Trans. Microw Theory Tech. MTT-y, No. 4, 447 (1959).

Chemical structure and stability relationships in polymers, B. G. Achhammer, M. Tryon, and G. M. Kline, Kunstoffe combined with German Plastics Digest 49, No. 11, 600 (1959); Mod. Plastics 37, No. 4, 131 (1959).

A study of $17-7 p \mathrm{H}$ stainless steel, N. L. Carwile and S. J. Rosenberg, WADC Tech. Rept. 58-653 (1959). Available from the Office of Technical Services, Department of Commerce, Washington 25, D.C

High-altitude observation techniques, D. M. Gates, Letter Sei. 131, 266 (1960).

The relation between confidence intervals and tests of significance - teaching aid, M. G. Natrella, Am. Stat. 14, No. 1, $20(1960)$

Electrophoretic deposition of metals, metalloids, and refractory oxides, V. A. Lamb and W. R. Reid, Plating 4\%, No. 3 291 (1960)

The effect of the earth's magnetic field on m.u.f. calculations, K. Davies, J. Atmospheric and Terrest. Phys. 16, 187 (1959).

Fusion of polymer networks formed from linear polyethylene: Effect of intermolecular order, L. Mandelkern, D. E Roberts, J. C. Halpin, and F. P. Price, J. Am. Chem. Soc. 82, $46(1960)$.

Determination of the recording performance of a tape from it magnetic properties, E. D. Daniel and I. Levine, J. Acoust. Soc. Am. 32, No. 2, 258 (1960).

Sauter theory of the photoelectric effect, U. Fano, K. W MeVoy, and J. R. Albers, Phys. Rev. 116, No. 5, 1147 (1959).

Bremsstrahlung and the photoelectric effect as inverse processes, K. W. MeVoy and U. Fano, Phys. Rev. 116, No. 5, 1168 (1959).

Surface area and exchange capacity relation in a Florida kaolinite, W. C. Ormsby and J. M. Shartsis, J. Am. Ceram. Soc. 43, No. 1, 44 (1960)

Balmer decrements: the diffuse nebulae, S. R. Pottasch, Astrophys. J. 131, No. 1, 202 (1960).

Standard frequency transmission and time signals, W. D. George, Proc. 2d all-IRIG Symp., prepared by Secretariat, Inter-Range Instrumentation Group, Oct. 1958, p. 141, IRIG Document No. 107-58 (1959).

Atomistic approach to the rheology of sand-water and claywater mixtures, W. A. Weyl and W. C. Ormsby, ch. 7 vol. III, Rheology - Theory and applications, edited by F. R. Eirich, p. 249 (Academic Press, New York, N.Y., 1960).

Diffusion of particles in turbulent flow, C. M. Tehen, Adv. Geophys. 6: Atmospheric diffusion and air pollution, p. 165 , Proc. Symp. Oxford, England, Aug. 1958 (Academic Press Inc. New York, N.Y., 1959). 
Atmospheric tides and ionospheric electrodynamics, M. L. White, J. Geophys. Research 65, 153 (1960).

Some evidence for structural anomalies in pure cristobalite, R. F. Walker, S. J. Schneider, and R. S. Roth, J. Am. Ceram. Soc. 42, No. 12, 642 (1959).

La Recherche sur les radicaux libres au National Bureau of Standards, H. P. Broida, J. chim. phys. 56, No. 2392, 813 (1959).

Isotope exchange processes in solid nitrogen under electron bombardment, R. Klein and E. M. Horl, J. Chem. Phys. 32, No. 1, 307 (1960).

Are life testing procedures robust? M. Zelen and M. C. Dannemiller, Proc. 6th Natl. Symp. Reliability and Quality Control in Electronies, Jan. 11-13, 1960, Inst. Radio Engrs. Inc., p. 185 (1960).

Relative measurement of the photodetachment cross section for $\mathrm{H}^{-}$, S. J. Smith and D. S. Burch, Phys. Rev. 116, No. 5, 1125 (1959).

Interference of orbital and spin currents on bremsstrahlung and photoelectric effect, U. Fano, K. W. McVoy, and J. R. Albers, Phys. Rev. 116, No. 5, 1159 (1959)

Reception of space diversity transmitters, J. W. Koch, Wireless World (England) 65, No. 10, 512 (1959).

Improved NBS abrasive jet method for measuring abrasion resistance of coatings, A. G. Roberts, ASTM Bull. No. 244, 48 (TP52) (1960)

Flame-spread measurements by the radiant panel flamespread method, D. Gross, Forest Products J. X, No. 1, 33 (1960)

Reactions en chaine de radicaux geles, J. L. Jackson, J. chim. phys. 56, No. 2392, 771 (1959).

Etude spectroscopique des produits de la decharge electrique dan L'Azote condenses a l'etat solide a tres basse temperature, prevues en faveur de l'existence d'Azote triatomique dans le solide, M. Peyron, E. M. Horl, H. W. Brown, and H. P. Broida, J. chim. phys. 56, No. 2392, 736 (1959).

Apparent temperatures measured at melting points of some metal oxides in a solar furnace, J. J. Diamond and S. J. Schneider, J. Am. Ceram. Soc. 43, No. 1, 1 (1960).

What price accurate test methods? A. T. McPherson, ASTM Bull. (ACR Notes Column) No. 244, 7 (1960).

Perovskite-type compounds in binary rare earth oxide systems, S. J. Schneider and R. S. Roth, J. Am. Ceram. Soc. 43, No. 2, 115 (1960).

Use of disodium m-benzenedisulfonate as a hardening agent in Watts nickel bath, W. H. Metzger, P. A. Krasley, and F. Ogburn, Plating 47, No. 3, 285 (1960).

An analysis of time variations in tropospheric refractive index and apparent radio path length, M. C. Thompson, H. B. Janes, and A. W. Kirkpatrick, J. Geophys. Research 65, 193 (1960).

Neutron detection by reactions induced in scintillators, C. O Muehlhause, Pt. I, Fast neutron physics, sec. III, Pt. III. B, p. 387 (Interscience Publ., New York, N.Y., 1960).

A relationship between the lower ionosphere and the [OI] 5577 nightglow emission, J. W. MeCaulley and W. S. Hough, J. Geophys. Research 64, No. 12, 2307 (1959).

Many changes reflected in new dry cell standard, W. J. Hamer, Mag. of Standards 31, No. 3, 81 (1960).

Etude aux infrarouges de certains solides condenses a partir de decharges en phase gazeuse, K. B. Harvey and H. W. Brown, J. chim. phys. 56, No. 2392, 745 (1959).

Water penetration testing machine for sole leather, T. J. Carter, J. Am. Leather Chemists Assoc. LV, No. 3, 139 (1960).

Theory of flame propagation in solid nitrogen at low temperatures, S. G. Reed and C. M. Herzfeld, J. chem. phys. 32, No. 1, 1 (1960).

A note regarding the mechanism of UHF propagation beyond the horizon, A. D. Watt, E. F. Florman, and R. W. Plush, Letter Proc. IRE 48, 252 (1960).

High-frequency limit of bremsstrahlung in the Sauter approximation, U. Fano, Phys. Rev. 116, No. 5, 1156 (1959).

The weighted compounding of two independent significance tests, M. Zelen and L. S. Joel, Ann. Math. Stat. 30, No. 4, 885 (1959).

A model of the $F$ region above $h_{\max } F 2$, J. W. Wright, J. Geophys. Research 65, 185 (1960).
Interference of antioxidant in the determination of low polymer in SBR synthetic rubber, L. T. Milliken and F. J. Linnig, J. Polymer Sci. XLI, No. 138, 544 (1959).

Physical properties of synthetic-rubber-base dental impression materials, W. A. C. Miller, Jr., W. C. Hansen, G. Dickson, and W. T. Sweeney, J. Am. Dental Assoc. 60, 211 (1960),

The effect of multipath distortion on the choice of operating frequencies for high-frequency communication circuits, D. K. Bailey, IRE Trans. Ant. Prop. AP-7, No. 4, 397 (1959).

Microwave absorption in compressed oxygen, A. A. Maryott and G. Birnbaum, J. Chem. Phys. 32, No. 3, 686 (1960).

Liquid hydrogen from chemical and nuclear rockets, R. B. Scott, Discovery XXI, No, 2, 74 (1960).

Studies of infrared absorption spectra of solids at high pressures, E. R. Lippincott, C. E. Weir, A. Van Valkenburg, and E. N. Bunting, Spectrochim. Acta 16, p. 58 (1960).

Phosphorescence of nitrogen and nitrogen-argon deposited films at $4.2^{\circ} \mathrm{K}, \mathrm{H}$. P. Broida and R. W. Nicholls, J. Chem. Phys. 32, No. 2, 623 (1960)

Nickel-aluminum alloy coatings produced by electrodeposition and diffusion, D. E. Couch and J. H. Connor, J. Electrochem. Soc. 10\%, No. 4, 272 (1960).

Energy requirements of mechanical shear degradation in concentrated polymer solutions, A. B. Bestul, J. Chem. Phys. 32, No. 2, 350 (1960)

Peculiarities of the ionosphere in the far east: A report on IGY observations of sporadic $E$ - and $F$-region scatter, E. K. Smith, Jr., and J. W. Finney, J. Geophys. Research 65, $885(1960)$.

Detecting radiation, L. Costrell, Chem. Eng. News, p. 132 (1960).

Several new methods to measure the thermal diffusivity of semiconductors, J. H. Becker, J. Appl. Phys. 31, No. 3, $612(1960)$

Opportunities in dental research, G. C. Paffenbarger, J. Am. Dental Assoc. 60, 413 (1960).

Departures of hydrogen from L.T.E. in a stellar atmosphere and the consequent structure of the solar chromosphere, S. R. Pottasch, Commun. Observatoire Roy. Belgique No. 157, entitled, The empirical determination of the stellar photospheric structure, Paper 11, 67 (1959).

Low-temperature transport properties of commercial metals and alloys. III. Gold-cobalt, R. L. Powell, M. D. Bunch, and E. F. Gibson, J. Appl. Phys. 3, 504 (1960).

Pilot plant data for hydrogen isotope distillation, T. M. Flynn, Chem. Engr. Progr. 56, No. 3, 37 (1960).

VLF phase characteristics deduced from atmospheric waveforms, A. G. Jean, W. L. Taylor, and J. R. Wait, J. Geophys. Research 65, 907 (1960).

Correlation effects in impurity diffusion, J. R. Manning, Phys. Rev, 116, No. 4, 819 (1959).

Short-wave fadeouts without reported flares, H. DeMastus and M. Wood, J. Geophys. Research 65, No. 2, 609 (1960)

On the propagation of ELF radio waves and the influence of a nonhomogeneous ionosphere, J. R. Wait, J. Geophys. Research 65, No. 2, 597 (1960).

Precision Zeeman modulation microwave spectrometer, R. W. Zimmerer, Rev. Sci. Instr. 31, 106 (1960).

Chemistry, food, and civilization, A. T. MePherson, J. Wash. Acad. Sci. 50, No. 3, 1 (1960).

World maps of $F 2$ critical frequencies and maximum usable frequency factors for use in making ionospheric radio predictions, D. H. Zacharisen and V. Agy, J. Geophys. Research 65, 593 (1960).

Recent experimental evidence favouring the $p \mathrm{~K}_{1}(p)$ correlation function for describing the turbulence of refractivity in the troposphere and stratosphere, K. A. Norton, J. Atmospheric and Terrest. Phys. 15, 206 (1959).

Cavity resonator dielectric measurements on rod samples, H. Bussey, Insulation, p. 26 (1959).

Low-temperature transport properties of commercial metals and alloys. II. Aluminums, R. L. Powell, W. J. Hall, and H. M. Roder, J. Appl. Phys. 31, 496 (1960).

Prediction of sunspot numbers for cycle 20, W. B. Chadwick, Nature, p. 1787 (1959).

The melting of crystalline polymers, L. Mandelkern, Rubber Chem. and Technol. XXXII, No. 5, 1392 (1959). 
Sampling of leather, J. Mandel and C. W. Mann, J. Sci. and Ind. Research 18A, No. 12, 575 (1959).

Infrared studies of dense forms of ice, E. R. Lippincott, C. E. Weir, and A. Van Valkenberg, Commun. to Editor, J. Chem. Phys. 32, No. 3, 612 (1960).

A technique for reducing errors in permeability measurements with coils, B. L. Danielson and R. D. Harrington, Proc. IRE 48, No. 3, 365 (1960).

Atmospheric limitations on electronic distance measuring equipment, M. C. Thompson, Jr., H. B. Janes, and F. E. Freethey, J. Geophys. Research 65, 389 (1960).

Proposed specification for impression material; synthetic rubber base, dental, W. A. C. Miller, Jr., W. C. Hansen, G. Dickson, and W. T. Sweeney, J. Am. Dental Assoc. 60, 224 (1960).

Some results on the cross-capacitances per unit length of cylindrical three-terminal capacitors with thin dielectric films on their electrodes, D. G. Lampard and R. D. Cutkosky, Inst. Elec. Engrs. (London, England) Monograph No. 351 M, 1 (1960).
Low temperature phase transition of colemanite, A. Perloff and S. Block, Letter to Editor, Am. Mineralogist, p. 229 (1960).

A class of non-linear dielectric materials, P. H. Fang, R. S. Roth, and H. Johnson, J. Am. Ceram. Soc. 43, p. 169 (1960).

* Publications for which a price is indicated (except for NBS Technical Notes) are available only from the Superintendent of Documents, U.S. Government Printing Office, Washington 25, D.C. (foreign postage, one-fourth additional). Technical Notes are available only from the Office of Technical Services, U.S. Department of Commerce, Washington 25, D.C. (Order by PB number.) Reprints from outside journals and the NBS Journal of Research may often be obtained directly from the authors. 